\title{
SIMULATION OF POTENTIAL DISTRIBUTION AND MIGRATION OF ALNUS SPP. UNDER CLIMATE CHANGE
}

\author{
SAKALLI, A. \\ Faculty of Marine Sciences and Technology, Iskenderun Technical University \\ P.O. Box 31200 Iskenderun, Hatay, Turkey \\ phone: +90-3-26-614-1693; fax: +90-3-26-614-1877 \\ e-mail: abdulla.sakalli@iste.edu.tr \\ (Received 23 $3^{\text {rd }}$ Mar 2017; accepted 24 ${ }^{\text {th }}$ Aug 2017)
}

\begin{abstract}
Plant migration is a well-known adaptation strategy of plant groups or species with evidence from historical to present observation and monitoring studies. Importance of $\mathrm{N}_{2}$-fixing plants has increased in last decades. Alnus (alder) is an important plant group because of its nitrogen fixation ability. Alders are generally distributed in humid locations of boreal, temperate and tropical climate zones, where the nitrogen fixation is an important nitrogen source for other plants. To model the nitrogen fixation by alder, data about the global distribution of alder is absolutely required. In this study, a new method and model (Alnus-Distribution-Model (ADM)) are presented to predict the distribution of $\mathrm{N}_{2}$-fixing genus on global scale and its migration in the future by using climate change scenarios up to 2300 . Results of the study showed that the potential distribution of Alnus spp. not only depending on solitary use of climate variables, soil types and vegetation groups but on combined effect of all tree influencing variables. The ADM also presented that the Alnus spp. potentially will migrate mainly northwards in the northern hemisphere. This study covered basic approaches to understand the combine effect of climate, soil and vegetation on modelling of plant distribution and migration.
\end{abstract}

Keywords: Alnus, plant distribution, plant migration, nitrogen fixation, climate change, $R C P$ scenarios

\section{Introduction}

Since the nitrogen is a key factor for carbon uptake processes by photosynthetic organisms, and the main resource of the available nitrogen for biogeochemical processes in ecosystems is the $\mathrm{N}_{2}$ fixation by the symbiotic pathways between the host plants and $\mathrm{N}_{2}$-fixing bacteria, the determination of distribution of the host plants has been gaining very important meaning and role in modelling of biogeochemical cycles in the ecosystems. Numerous biogeochemical and biome models use empirical or statistical methods to predict the nitrogen fixation by $\mathrm{N}_{2}$ fixing plants (Prentice et al., 1992; Vitousek et al., 2002; Galloway et al., 2004; Esser et al., 2011). However, none of them considers the $\mathrm{N}_{2}$ fixation by alders since there is limited information about the distribution of alder species on global scale. It makes difficult to implement the fixation process in biogeochemical, biome models to investigate the interactions between the carbon and nitrogen biogeochemical cycles. It is well known that plants can change their distribution with time, when environmental conditions (i.e. soil, climate etc.) and biological factors (i.e. plant-plant interaction) change in their distributed regions (Sauer, 1988; Dawis and Zabinski, 1992; Iverson and Prasad, 2002). Overpeck et al. (1991) and Bartlein et al. (1997) published new data about widening capability of trees due to the change in environmental conditions. Climate change in the $21^{\text {st }}$ and $23^{\text {rd }}$ centuries that mainly driven by emission change and its impacts on different sectors has been addressed by numerous studies and projects. It is also documented that rapid climate change may put some species at risk of extinction, and possibly reduce the functionality of ecosystems, which could have consequences for ecosystem processes such as global 
carbon storage and biodiversity (Thomas et al., 2003). Furthermore, a change in the land cover due to migration of plant species can also affect greenhouse gas concentration in the atmosphere, since for instance a migration of nitrogen fixing plants can influence the carbon uptake and nitrogen availability in soil (Kurz and Apps, 1999). In recent years, the importance of the nitrogen cycle for the sequestration of atmospheric carbon dioxide in the terrestrial biosphere has become obvious (Vitousek et al., 2002; Galloway et al., 2004; Reich et al., 2006; Wang et al., 2007; Esser et al., 2011). While the fixation of $\mathrm{CO}_{2}$ by photosynthesis produces carbohydrates, nitrogen is required to bind carbon into phytomass. If the biospheric carbon pools increases, an adequate increase of the biospheric nitrogen pools is required. Atmospheric $\mathrm{N}_{2}$ may be incorporated in the biosphere, but only a limited number of organisms are able to fix it, because of the high activation energy for the decomposition. These organisms are free-living or symbiotic cyanobacteria, actinomycetes, and bacteria in roots of host plants (Galloway, 2002). Not only $\mathrm{N}_{2}$-fixing bacteria but also host plants that supply required energy for the fixation to the bacteria have enormous importance for the ecosystems. Most of the host plants belong to the families Fabaceae, Mimosaceae, Caesalpiniaceae (legumes) as well as to the Betulaceae (alder spp.), and they are called $\mathrm{N}_{2}$-fixing plants (Saikia and Jain, 2007; Lepper and Fleschner, 1977). Because of their participation in the $\mathrm{N}_{2}$ fixation, the modelling of distribution of the $\mathrm{N}_{2}$-fixing plant species plays a key role in earth system and ecosystem modelling. A spatial change in distribution areas of the nitrogen fixers affects directly available nitrogen in soil, carbon uptake and allocations in the biosphere (Galloway et al., 2004). Numerous ecosystem and biogeochemical models aim to predict the nitrogen fixation by using empirical functions (Vitousek et al., 2002; Wang et al., 2007; Galloway, 2002; Esser, 2007). Still, the modelling of nitrogen fixation by alders is missing in most of the models. To predict the amount of fixed nitrogen under global climate change conditions, it is indispensable to have a mechanistic description of the $\mathrm{N}_{2}$ fixation. And also, the description of the distribution of the symbiont's host plants, their density distribution in the vegetation types in which they occur, the type and the number of root nodules, and the activity of the nitrogen fixing enzyme systems in the nodules are needed. For instance, the density of alders in their native locations in Europe is mainly between 0 and $40 \%$ of total plant biomass (Skjøth et al., 2008). These percentage provide a possibility for a modelling the distribution and alders' biomass density according total plant biomass in a location by using models like NitrogenCarbon-Interaction-Model (NCIM) (Esser et al., 2011). Alder roots are generally infected with the symbiotic endophytic genus Frankia. As a symbiont, Frankia can convert atmospheric $\mathrm{N}_{2}$ into reactive nitrogen usable by using the supplied carbohydrates from alders as energy source (Myrold and Huss-Dannel, 1994; Schwintzer and Tjepkema, 1990; Binkley, 1994). Thus, the $\mathrm{N}_{2}$ fixation by alders can range from $20 \mathrm{~kg} \cdot \mathrm{ha}-1 \cdot \mathrm{yr}-1$ (Binkley, 1994) to $320 \mathrm{~kg} \cdot \mathrm{ha}-1 \cdot \mathrm{yr}-1$ (Van Miegroet et al., 1989). Therefore, alders play an important role in the respective ecosystems due to its ability to enrich poor soils with reactive nitrogen compounds. About 30 species belong to the genus alder, and to the family Betulaceae. The species are mainly distributed in the northern boreal and temperate zones e.g. Alnus glutinosa (L.) Gaerten, A. incana (L.) Moench, A. viridis (Chaix) D. C., A. rubra Bong., A. oblongifolia Torr, and A. serrulata (Ait.) Willd (Tutin et al., 2001). Some species extend into the subpolar zones, including A. hirsuta (Fischer) C.K. Schneider, A. viridis (Chaix) DC (Wiedmer and Senn-Irlet, 2006). In the Mediterranean zone occurs for example A. cordata (Loisel.) Duby. (Quézel et al., 1999). Numerous species are native to the mountains of the 
subtropical and tropical zones. A. nitida (Spach) Endl. occurs in the temperate Himalayas in altitudes from 1000 to $2900 \mathrm{~m}$ (Nasir, 1975). A. nepalensis D. Don is widely distributed in southeast Asia from subtropical China, Indochina, the Burmese (Shin) Hills, to the Himalayas in altitudes between 300 and 3000 m (Dai et al., 2004). Some alder species also distribute in the southern temperate zone, e.g. A. acuminata HBK, and the evergreen A. jorullensis Kunth are found in the Chilean Andes at high altitude (Reese, 2003). Within the distribution area of the alders the mean annual temperature is reported to range from $-14{ }^{\circ} \mathrm{C}$ to more than $20{ }^{\circ} \mathrm{C}$ (NACS, 1980). The annual precipitation probably ranges from less than $150 \mathrm{~mm}$ (WRCC, 2009; Hagenstein and Rickets, 2001) to more than $5600 \mathrm{~mm}$ (Harrington, 1991). Alder species prefer poor soils of various particle sizes from gravel and sand to silt, loam, and even clay as well as organic soils. Most species occur on fenlands, in swamp areas, along brooks, rivers, and streams in bogs, but regularly not in riparian areas with highly varying water levels. However, some species such as A. firma Sieb. \& Zucc. and A. crispa (Dryand. in Ait.) Pursh are distribute steep slopes. Several studies show that the main factors that influence the distribution of plant species in their natural ecosystem are climatic factors like temperature and precipitation (Woodward, 1996; Dukes and Mooney, 1999; Walther et al., 2002). Not only the climate change is a critical factor for plant distribution, but also the soil units via their different physical or/and chemical conditions can influence plant distribution (Brown, 1984; Min and Kim, 1999; Wu et al., 2011). Therefore, the soil units should be considered in the modelling studies about the prediction of plant distribution. Also, the occurrence of a plant species in its natural area is depending on plant-plant interactions. Plant species often favor to grow with specific other species (Pyke and Archer, 1991; Brooker, 2006). Several models like NCIM (Esser et al., 2011), LPJ-GUESS (Smith et al., 2001), and EMEP (Simpson et al., 2012) consider plant-plant interactions due to use potential natural vegetation groups or biome units in the model simulations.

In this paper, the aims were reported for modelling the global distribution of the $\mathrm{N}_{2}$ fixing host genus alder, and then the effect of climate change effect on the globally Alnus distribution. To predict the global distribution of alders, an available gridded data sets on climate, soil units and potential natural vegetation groups will be used. The individual contribution of each data type was tested for the correctness of the predicted distribution. This work should be a first step to predict the potential occurrence and distribution of alders depending on their climate requirements, soil conditions, and plant-plant interactions. This study should also give the basic information for implementation of $\mathrm{N}_{2}$-fixation by alders in biogeochemical and ecosystem models since $\mathrm{N}_{2}$ fixation is directly depending on the occurrence of $\mathrm{N}_{2}$-fixing plants in the terrestrial ecosystem.

\section{Materials and methods}

In this paper, a new model based on four progress steps was developed for the predicting of the potential distribution of alder spp. on the global scale. This new model is called "Alnus-Distribution-Model (ADM)". In the first step, the values of annual average temperature and precipitation were used from Leemans and Cramer $0.5^{\circ}$ degree grid element global climate database (Cramer and Leemans, 1991) to define a bioclimatic niche of Alnus spp. The climate database includes 30 years (1961-1990) average of the climate parameters for $0.5^{\circ}$ resolution on the global scale. In the second 
step, the climate based ADM was extended with soil units by using the FAO soil classification (1974) in "Soil Types of the World" (FAO-Unesco, 1974). In the third step, the climate parameters based ADM was extended with potential natural vegetation groups after Esser et al. (2011). The vegetation data set is our own digitized database from the "Atlas for Biogeography" after Schmithüşsen (1976). The vegetation map after Schmithüsen comprises 176 vegetation units globally. These 176 vegetation units were aggregated in 31 potential natural vegetation groups in the research group at the institute, and it published in the study Esser et al. (2011). In the fourth step, all three methods were merged to predict the potential alders' distribution by the ADM. The used climate, soil, and vegetation data sets are on identical global grid resolution, i.e. half degree longitude and latitude as commonly used by global vegetation models. 62483 grid elements are characterized for the land areas excluding Antarctica. Each grid element is characterized by its lower left (south-east) corner coordinate in decimal degrees.

\section{Distribution data for alders}

For the construction of ADM, the global distribution data for of the Alnus spp. were extracted from seven databases (Tropicos.org, 2009; eFloras, 2008; WWF, 2009; Tutin et al., 2001; US Forest Service, 2008; USDA-NRCS, 2009; Li and Skvortsov, 1999). The number of data for alder occurrence is very unevenly distributed worldwide. The name of the alders' species, the altitude, and the coordinates of the origin place were collected. A total of 308 locations including the data were extracted. All species of genus Alnus Mill. of Table 1 are represented in the 308 locations. The lifespan of alders ranges between 40-100 years (Harrington et al., 1994; Claessens et al., 2010). It is assumed that a change in the 30-year annual average of climate conditions (i.e. temperature and precipitation) can change the suitable climate conditions in the distribution area and force the migration of alder species. Unfortunately, there is data for validation of this assumption in the academic literature databases. Therefore the 30year period was used for the prediction of alder distribution and migration. This is a weak point of the model, and may be changed in the future by long-term observation studies.

Table 1. The global distributed 34 alder species, which were used for selection of the locations and the relevant climate, soil, and vegetation parameters. The species names are according to the publication from Chen and $\mathrm{Li}$ (2004).

\begin{tabular}{|c|c|}
\hline Species name & Species name \\
\hline A. acuminata HBK & A. matsumurae Callier \\
\hline A. barbata C. A. Mey & A. maximowiczii Callier \\
\hline A. cordata (Loisel.) Duby. & A. nepalensis D. Don \\
\hline A. cremastogyne Burkill & A. nitida (Spach) Endl. \\
\hline A. crispa (Dryand. in Ait.) Pursh & A. oblongifolia Torr \\
\hline A. fernandi-coburgii C.K. Schneider & A. orientalis Decne \\
\hline A. firma Sieb. and Zucc. & A. pendula Matsum \\
\hline A. formasana (Burkill) Makino & A. rhombifolia Nutt. \\
\hline A. fruticosa (Du Roi) Spreng. & A. rubra Bong. \\
\hline A. glutinosa (L.) Gaerten & A. rugosa (Du Roi) Spreng. \\
\hline A. hirsuta (Fischer) C.K. Schneider & A. serrulata (Ait.) Willd \\
\hline A. incana (L.) Moench & A. sieboldiana Matsum \\
\hline A. inokumae S. Murai and Kusaka. & A. sinuata (Regel) Rydb. \\
\hline
\end{tabular}




\begin{tabular}{l|l}
\hline A. japonica (Thunb.) Steud. & A. subcordata C.A. Mey \\
A. jorullensis Kunth & A. tenuifolia Nutt. \\
A. mandshurica C. K. Schneider & A. trabeculosa Hand. and Mazz \\
A. maritima (Marsh.) Nutt. & A. viridis (Chaix) D. C. \\
\hline
\end{tabular}

\section{"Clim"}

I determined the grid elements, in which alders occur in the 308 sites. All further analyses were made by using the gridded data sets. First, the mean annual temperature $\left(\mathrm{T}_{\mathrm{ann}}\right)$ and annual total amounts of precipitation $\left(\mathrm{P}_{\mathrm{ann}}\right)$ were extracted from the gridded climate data set for the sites of alders. The altitudes of the alder locations within a grid element may deviate from the mean altitude of the grid element. Therefore, corrections of the gridded climate data were sometimes necessary. For this purpose, the altitude of the site that was given in the original databases was used. If altitudes were lacking, it was determined from the GTOPO30 global elevation dataset (GTOPO30, 2010). If the altitude could not be determined, the side was eliminated. The nearby climate stations were selected from Walter and Lieth (1961-1967), Müller (1982) and Mitchell and Jones (2005). The arrays of $\mathrm{T}_{\mathrm{ann}}$ and $\mathrm{P}_{\mathrm{ann}}$ were plotted for the 308 alder sites. Three linear functions were then determined which envelop the field of climate data of the alder sites. The $\mathrm{T}_{\mathrm{ann}}$ and $\mathrm{P}_{\mathrm{ann}}$ values of the 308 locations were presented in the Fig. 2. three linear functions F1-F3 were fitted to the six cardinal points P1-P6:

$\mathrm{F} 1(\mathrm{P} 1, \mathrm{P} 2)$; F2(P3, P4); F3(P5, P6). The three linear functions that form the borderlines of alder distribution in the temperature-precipitation matrix are:

$$
\begin{gathered}
F_{1}(x)=-2.04 * x+172.58 \\
F_{2}(x)=-561.58 * x+16141.87 \\
F_{3}(x)=110.67 * x+1658.64
\end{gathered}
$$

The $x$ equals to $\mathrm{T}_{\text {ann }}\left({ }^{\circ} \mathrm{C}\right)$ and $F_{(1,2,3)}(x)$ to $\mathrm{P}_{\text {ann }}(\mathrm{mm})$. In Figure 2 plot of these functions can also be found.

To determine the potential distribution areas for alders, the following climate based method was used:

$$
D_{\text {Clim }, i}=\left\{\begin{array}{l}
\text { true, if } \text { Clim }_{T_{\text {ann }}, P_{\text {ann }, i}} \text { inside climate matrix field } \\
\text { false, else }
\end{array}\right.
$$

where $i$ is grid number of half degree grid element, $\mathrm{T}_{\mathrm{ann}}\left({ }^{\circ} \mathrm{C}\right)$ is mean annual temperature, and $P_{a n n}(\mathrm{~mm})$ is annual total amounts of precipitation of the grid element, respectively. The distribution of alder species based on climate parameter $\left(\mathrm{D}_{\mathrm{Clim}, \mathrm{i}}\right)$ is true in a grid element if the certain criteria of the grid element are fulfilled (see $E q .4$ ).

\section{"Soil"}

For this aim, the FAO soil units from the "Soil Types of the World" database, which 
includes 129 soil units for the $0.5^{\circ}$ grid cells of the terrestrial biosphere (excl. Antarctic) (FAO-Unesco, 1974) were used to enhance the climate based ADM for prediction of potential alders distribution. The soil units of the 308 study sites, in which the alders natively occur were recorded as suitable soil types for the alder distribution. Thereby, the soil units were used as additional determinants for the alder occurrence. If a soil unit were present in only one grid element, it was not considered in the modelling study. Grid elements were marked as potential alder habitats, if they were within the climate field limited by the three linear functions of the temperature-precipitation field, and have suitable soil unit, which occurs in more than one grid elements with alder distribution. For this step, the following equation was used:

$$
D_{\text {Soil }, i}=\left\{\begin{array}{c}
\text { true, if }\left\{\begin{array}{c}
\text { Soil } \\
D_{\text {Clim }, i}=\text { Soil }_{a} \\
\text { true }
\end{array}\right. \\
\text { false, else }
\end{array}\right.
$$

where $i$ is grid number of half degree grid element, Soil ${ }_{i}$ is the soil unit of the grid element, and Soil $_{a}$ is the soil unit of the grid elements with data record about alder distribution in 308 study sites, respectively.

\section{“Veg”}

In this step, the 31 potential natural vegetation groups according to the study from Esser et al. (2011) were used to investigate the correlation between the alder distribution and climate-vegetation aspect in this study. The potential natural vegetation groups, in which alders occur natively were marked as suitable vegetation groups for alder distribution. Thereby, these potential natural vegetation groups were used as additional determinants for alder distribution. If a vegetation group was recorded in only one grid element, it was not considered in the modelling study. Grid elements were marked as potential alder habitats if they were within the climate field limited by the three linear functions of the temperature-precipitation field, and have suitable potential natural vegetation group which occurs in more than one grid elements with alder distribution. For this step, the following equation was used:

$$
D_{\text {Veg, }}=\left\{\begin{array}{l}
\text { true, if }\left\{\begin{array}{l}
V_{V^{\prime}}=V_{i}=g_{a} \\
D_{C l i m, i}=\text { true }
\end{array}\right. \\
\text { false,else }
\end{array}\right.
$$

where $i$ is grid number of half degree grid element, $V e g_{i}$ is the vegetation type of the grid element, and $V e g_{a}$ is the vegetation type of the grid elements with data record about alder distribution in 308 study sites, respectively.

\section{"All"}

In this step, all three method were combined for modelling of potential alder distribution. The verified the soil units, and the potential natural vegetation groups which occur in the grid elements with alder sites were used together as additional determinants for alder occurrence. The equation of this step is as follows: 


$$
D_{\text {All }, i}=\left\{\begin{array}{l}
\text { true, if }\left\{\begin{array}{l}
D_{\text {Clim }, i}=\text { true } \\
D_{\text {Soil }, i}=\text { true } \\
D_{\text {Veg }, i}=\text { true }
\end{array}\right. \\
\text { false, else }
\end{array}\right.
$$

where $i$ is grid number of half degree grid element.

\section{Migration of alder species in 2100 and 2300}

To predict the migration of alder species up to 2300 , data for $\mathrm{T}_{\text {ann }}$ and $\mathrm{P}_{\text {ann }}$ were needed. For this step, the mean annual value of temperature and precipitation of four RCP (Representative Concentration Pathway) scenarios (i.e. RCP 2.6, RCP 4.5, RCP 6.0 and RCP 8.5) were selected from the CCSM4 data model outputs for the period between 2000 and 2300. The climate data of the four different RCP scenarios was used for checking the potential effect of variability in temperature and precipitation on plant distribution (i.e. Alnus spp.) due to change in anthropogenic emission of greenhouse gases, technology and population density according to the RCP scenarios. Since the used climate data for the prediction of alder distribution in the "Clim" stage were the 30-year annual average data from Leemans and Cramer data base, 30-year annual average value of $T_{a n n}$ and $P_{a n n}$ from 2071 to 2100 , and from 2271 to 2300 were used for prediction of alder distribution in 2100 and 2300 , respectively. The 30 -year periods give plants the possibility for adaptation to the climate change in a location. To avoid the jump of alder species over long distance (i.e. more than one grid cell), it is also assumed that the alder cannot migrate to a grid cell if at least one of the neighbor grid cell was not marked as a potential distribution grid cell.

\section{Observations and statistical analyses}

The Global Biodiversity Occurrence Data Base (GBIF) (GBIF, 2010) was used for the evaluation of the model results. The database includes 237178 data records about the alder occurrence worldwide. Majority of these observations crowds together in a few regions of the world, while data in other regions are very scarce, so that the global coverage is very uneven. The database includes a global distribution map as well as the opportunity to download information amongst others the coordinate, name of the occurred alder species, and basis of records (unknown, herbarium, observed or specimen) in the locations. In the Table 4, 49 countries were presented, which were extracted from the database with data records about the alder distribution. Countries with just one data record for alder distribution or data records without the coordinate of the location or with the "unknown" basis of records were not considered in this study. Therefore, 215444 of 237178 were selected as useful data records in the 49 countries (see Table 4).

The prediction of the ADM model was validated with the data from the GBIF database for each step as well as for analyzing correlations between the observed and predicted data by calculation regression coefficient, index of agreement d (Willmott, 1982) (see Eq. 9), mean absolute error (MAE) (see $E q .8$ ) to determine the best method for the prediction of the alder distribution. The used $M A E$ and $\mathrm{d}$ equations are:

$$
M A E=\frac{1}{n} \sum_{i=1}^{n}\left|P_{i}-O_{i}\right|
$$




$$
\mathrm{d}=1-\frac{\sum_{\mathrm{i}=1}^{\mathrm{n}}\left(\mathrm{p}_{\mathrm{i}}-\mathrm{o}_{\mathrm{i}}\right)^{\mathrm{n}}}{\sum_{\mathrm{i}=\mathrm{i}}^{\mathrm{n}}\left(\left(\mid \mathrm{P}_{\mathrm{i}}-\mathrm{O}_{\mathrm{i}} \|\right)+\left(\| \mathrm{o}_{\mathrm{i}}-\sigma \mid\right)\right)}
$$

where $P$ is the number of the simulated grid cells with potential alder distribution in related locations and $O$ is the number of the observed grid cells with alder distribution, $i$ a sample, $n$ the number of samples, overbar represents mean values, and $d$ is the index of agreement, respectively.

a)

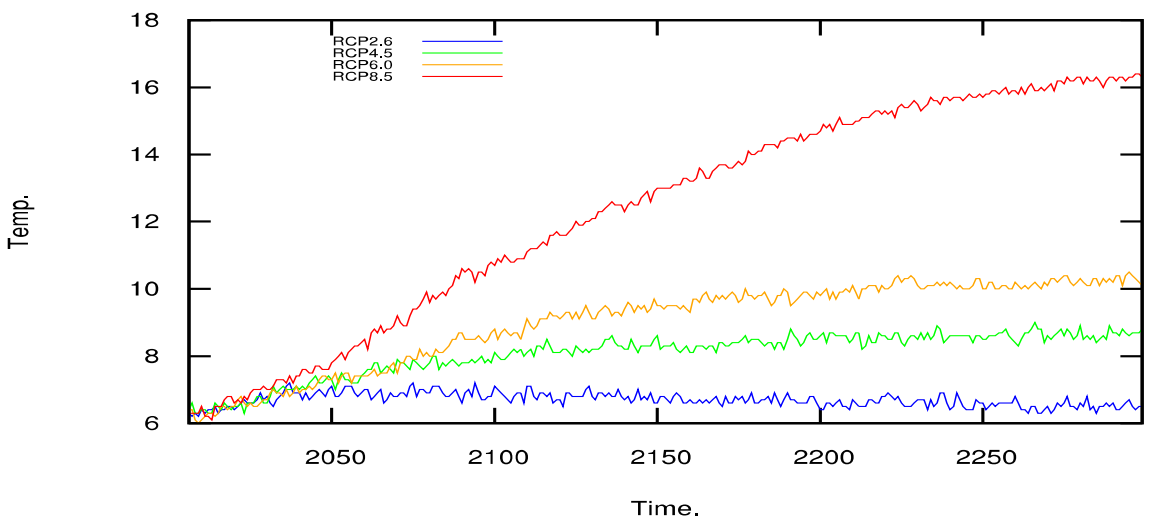

b)

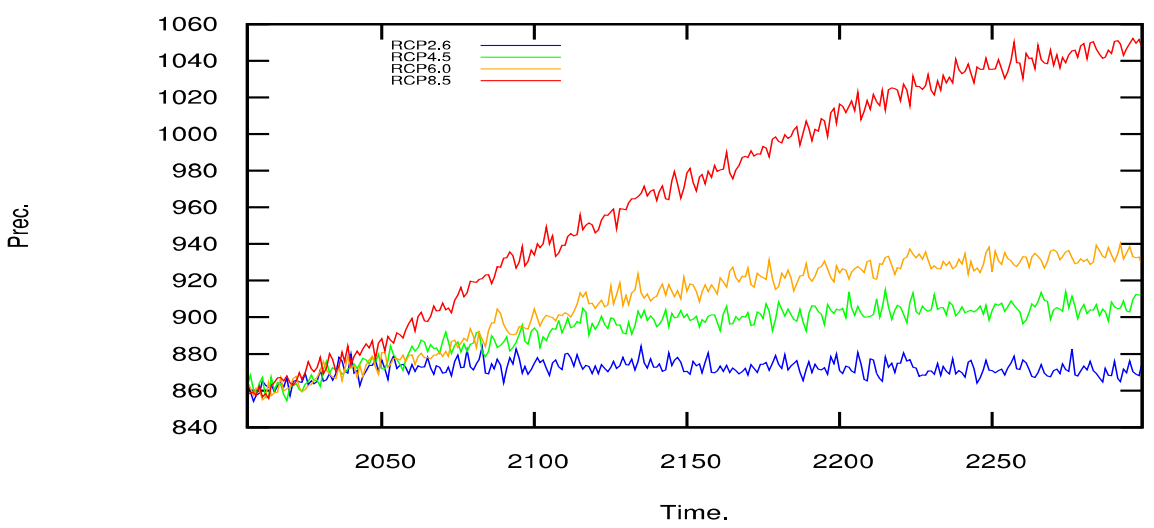

Figure 1. The change in global average temperature and precipitation (2006-2300) of CCSM4 model which driven by four RCP emission scenarios.

\section{Results}

\section{Evaluation of distribution methods}

In Figure 2, the distribution of the 308 data points in the field of $\mathrm{T}_{\mathrm{ann}}$ and $\mathrm{P}_{\mathrm{ann}}$ is shown. In the distribution regions, there is a lower limit of annual precipitation, which excludes the occurrence of alders. This lower limit depends also on $\mathrm{T}_{\mathrm{ann}}$. At the alder distribution sides, when the $\mathrm{T}_{\mathrm{ann}}$ around $-10{ }^{\circ} \mathrm{C}$ or colder, $\mathrm{P}_{\mathrm{ann}}$ limit is about at $190 \mathrm{~mm}$. When $\mathrm{T}_{\mathrm{ann}}$ is around $28^{\circ} \mathrm{C}$, the alders need about $115 \mathrm{~mm}$ annual precipitation for their existence. Since alders occur at low precipitation values mainly along rivers and brooks, it is assumed that the occurrence of alders in areas with low $\mathrm{P}_{\mathrm{ann}}$ is due to the probability of the suitable soil water content. 


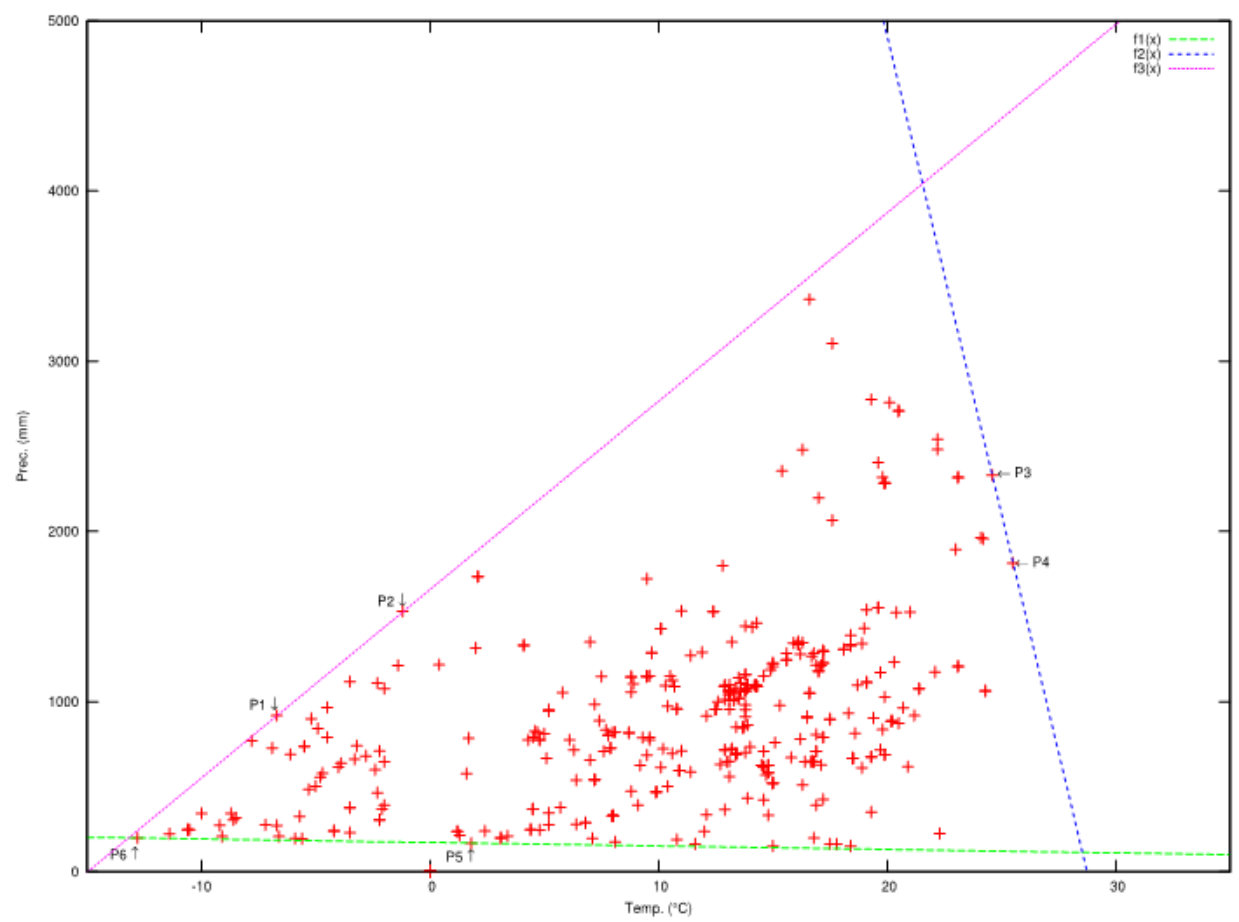

Figure 2. The temperature-precipitation field of the 308 data points which were extracted from seven data bases (Tropicos.org, 2009; eFloras, 2008; WWF, 2009; Tutin et al., 2001; US Forest

Service, 2008; USDA-NRCS, 2009; Li and Skvortsov, 1999) as sites of alder occurrence. The cardinal points $P 1, \ldots, P 6$ define the borderline of the distribution of alder in this field. They define the three linear functions 1 through 3 which were used to select appropriate grid elements from a global $0.5^{\circ}$ grid of climate data (Cramer and Leemans, 1991).

From the selected six cardinal points P1...P6 to define the borderline of the alder distribution in a matrix (see Figure 2), the point P1, P2 and P6 refers to Alnus viridis, which occurs in the northern boreal regions of Asia, Europe, and North America. In temperate regions, A. viridis may occur at high elevations (Kamruzzahan, 2003). $\mathrm{P}_{\mathrm{ann}}$ range for A. viridis. is between 150 and $3000 \mathrm{~mm} \mathrm{yr}^{-1}$ in its native distribution areas (Racine et al., 2001). The points P3 and P4 belong to the two species Alnus acuminata the Andean alder, and Alnus jorullensis the Mexican alder, which are native to the mountains of Central and South America. Their distribution defines the upper temperature limit of the alder distribution, which seems to be below $30{ }^{\circ} \mathrm{C}$ average annual temperature. In the regions, $\mathrm{P}_{\mathrm{ann}}$ may range from 500 to $4000 \mathrm{~mm} \mathrm{yr}^{-1}$. The point P5 refers to Alnus rhombifolia, which occurs in the lower areas of the northern Pacific coast of North America from humid to per-humid climates (USDA-NRCS, 2009). The $\mathrm{P}_{\mathrm{ann}}$ within the distribution areas of $A$. rhombifolia varies from 508 to $3175 \mathrm{~mm}$ per year, and the lowest temperature is $-4.4^{\circ} \mathrm{C}$ (USDA-NRCS, 2009).

\section{Further stages of the model}

The climate based ADM was refined by means of the soil units. The soil units that recorded in the 308 grid elements are shown in Table 2. The considered alder distribution areas involve 53 of 130 FAO soil units. Lithosols and Cambisols are the dominated soil units in the 308 distribution areas. About half the grid elements include the two soil units. Although, most of the alder species prefer to distribute in wet soils 
and in soils with high water availability, the Gleysols were found only in 21 of 308 grid elements. Gleysols are wetland soils and categorized in FAO-UNESCO soil database as a hydromorphic soil group, which are influenced by groundwater for a long period to develop a characteristics gleyic pattern, and are mainly covered by swamp vegetation (FAO-Unesco, 1974). The soil units, which were present in only one grid element, were not considered in this work.

Table 2. Soil units related to Soil Map of the World of FAO-UNESCO (1974) which dominate in the $0.5^{\circ}$ grid elements where alder species occur according to the GBIF database. The bold lines are the main groups of the related sub group for soil types according to FAO-UNESCO Soil Map of the World.

\begin{tabular}{|c|c|c|}
\hline Nr. of the grids & FAO unit & Soil name \\
\hline 78 & B & Cambisols \\
\hline 21 & BK & Calcic Cambisol \\
\hline 19 & $\mathrm{BD}$ & Dystric Cambisol \\
\hline 19 & $\mathrm{BE}$ & Eutric Cambisol \\
\hline 15 & $\mathrm{BH}$ & Humic Cambisol \\
\hline 2 & BG & Gleyic Cambisol \\
\hline 2 & BX & Gelic Cambisol \\
\hline 75 & I & Lithosols \\
\hline 35 & A & Acrisols \\
\hline 26 & $\mathrm{AO}$ & Orthic Acrisol \\
\hline 4 & $\mathrm{AF}$ & Ferric Acrisol \\
\hline 4 & $\mathrm{AH}$ & Humic Acrisol \\
\hline 1 & AG & Gleyic Acrisol \\
\hline 1 & AP & Plinthic Acrisol \\
\hline 22 & $\mathrm{P}$ & Podzols \\
\hline 17 & $\mathrm{PO}$ & Orthic Podzol \\
\hline 5 & PL & Leptic Podzol \\
\hline 20 & G & Gleysols \\
\hline 15 & GD & Dystric Gleysol \\
\hline 4 & GE & Eutric Gleysol \\
\hline 1 & GM & Mollic Gleysol \\
\hline 18 & $\mathrm{~L}$ & Luvisols \\
\hline 7 & LC & Chromic Luvisol \\
\hline 6 & LO & Orthic Luvisol \\
\hline 5 & LA & Albic Luvisol \\
\hline 14 & $\mathrm{~T}$ & Andosols \\
\hline 7 & TV & Vitric Andosol \\
\hline 5 & $\mathrm{TH}$ & Humic Andosol \\
\hline 2 & TM & Mollic Andosol \\
\hline 13 & $\mathrm{H}$ & Phaeozems \\
\hline 6 & $\mathrm{HG}$ & Gleyic Phaeozem \\
\hline 5 & $\mathrm{HL}$ & Luvic Phaeozem \\
\hline 2 & $\mathrm{HH}$ & Haplic Phaeozem \\
\hline 7 & $\mathrm{R}$ & Regosols \\
\hline 4 & RX & Gelic Regesol \\
\hline 2 & $\mathrm{RC}$ & Calcaric Regesol \\
\hline 1 & $\mathrm{RD}$ & Dystric Regesol \\
\hline 5 & Y & Yermosols \\
\hline 3 & YL & Luvic Yermosol \\
\hline
\end{tabular}




\begin{tabular}{c|c|c}
\hline $\mathbf{2}$ & YK & Calcic Yermosol \\
$\mathbf{4}$ & N & Nitosols \\
$\mathbf{4}$ & NE & Eutric Nitosol \\
$\mathbf{4}$ & O & Histosols \\
$\mathbf{4}$ & OX & Gelic Histosol \\
$\mathbf{3}$ & J & Fluvisols \\
$\mathbf{3}$ & JE & Eutric Fluvisol \\
$\mathbf{3}$ & U & Rankers \\
$\mathbf{3}$ & X & Xerosols \\
$\mathbf{2}$ & XH & Haplic Xerosol \\
$\mathbf{1}$ & XL & Luvic Xerosol \\
$\mathbf{1}$ & F & Ferrasols \\
$\mathbf{1}$ & FX & Xanthic Ferrasol \\
$\mathbf{1}$ & Kastanozems \\
$\mathbf{1}$ & KL & Luvic Kastanozem \\
$\mathbf{1}$ & W & Planosols \\
& WE & Eutric Planosol \\
\hline
\end{tabular}

In Table 3, the potential natural vegetation groups of the 308 grid elements after Esser et al. (2011) and their vegetation units which occur in digitized version of the atlas for bio-geography after Schmithüsen (1976) were shown. 50 of 176 vegetation units according to Schmithüsen (1976) were recorded in the 308 grid elements. The most common vegetation units in the distribution areas was the potential natural vegetation group "Temperate deciduous forests" (68 of 308 grid elements). In 97 locations, the tropical and subtropical potential natural vegetation groups were recorded. In 32 locations, dry vegetation units ("Open conif. dry woodland", "Conif. dry forest", "Puna dry steppe", "Drought-deciduous and part evergreen thorn bush formation", "Artemisia dry steppe", and "Trop. lowland dry forest") were found. In those locations, the alders may distribute in moist areas along rivers and streams. For instance, the "droughtdeciduous and part evergreen thorn bush formation" (7 sites) occurs on the east slopes of the Argentinian and southern Bolivian Andes, where a number of brooks and rivers are present. There are also 33 grid elements with sclerophyllous formations of Mediterranean type climates. These sites may also be supported by water currents occurring in these formations.

Table 3. The potential natural vegetation groups according to the study from Esser et al. (2011) (name with bold character) and the vegetation units according to Schmithüsen (1976) which occur in the $0.5^{\circ}$ grid elements which include the data records about alder occurrence. The left column gives the respective number of grid elements.

\begin{tabular}{c|c}
\hline Nr. of records & Name of the vegetation group \\
\hline $\mathbf{6 8}$ & Temperate deciduous forests \\
$\mathbf{2 2}$ & Cold-deciduous broadleafed forest w. evergreen conif. trees \\
$\mathbf{2 0}$ & Cold-deciduous mesophytic broadleafed forest \\
$\mathbf{6}$ & Submediterranean cold-deciduous broadleafed forest \\
$\mathbf{4}$ & Mountain cold-deciduous mesophytic broadleafed forest \\
$\mathbf{3}$ & Cold-deciduous mesophytic broadleafed forest w. Quercus \\
$\mathbf{3}$ & Cold-deciduous broadleafed forest w. evergreen broadleafed trees \\
\hline
\end{tabular}




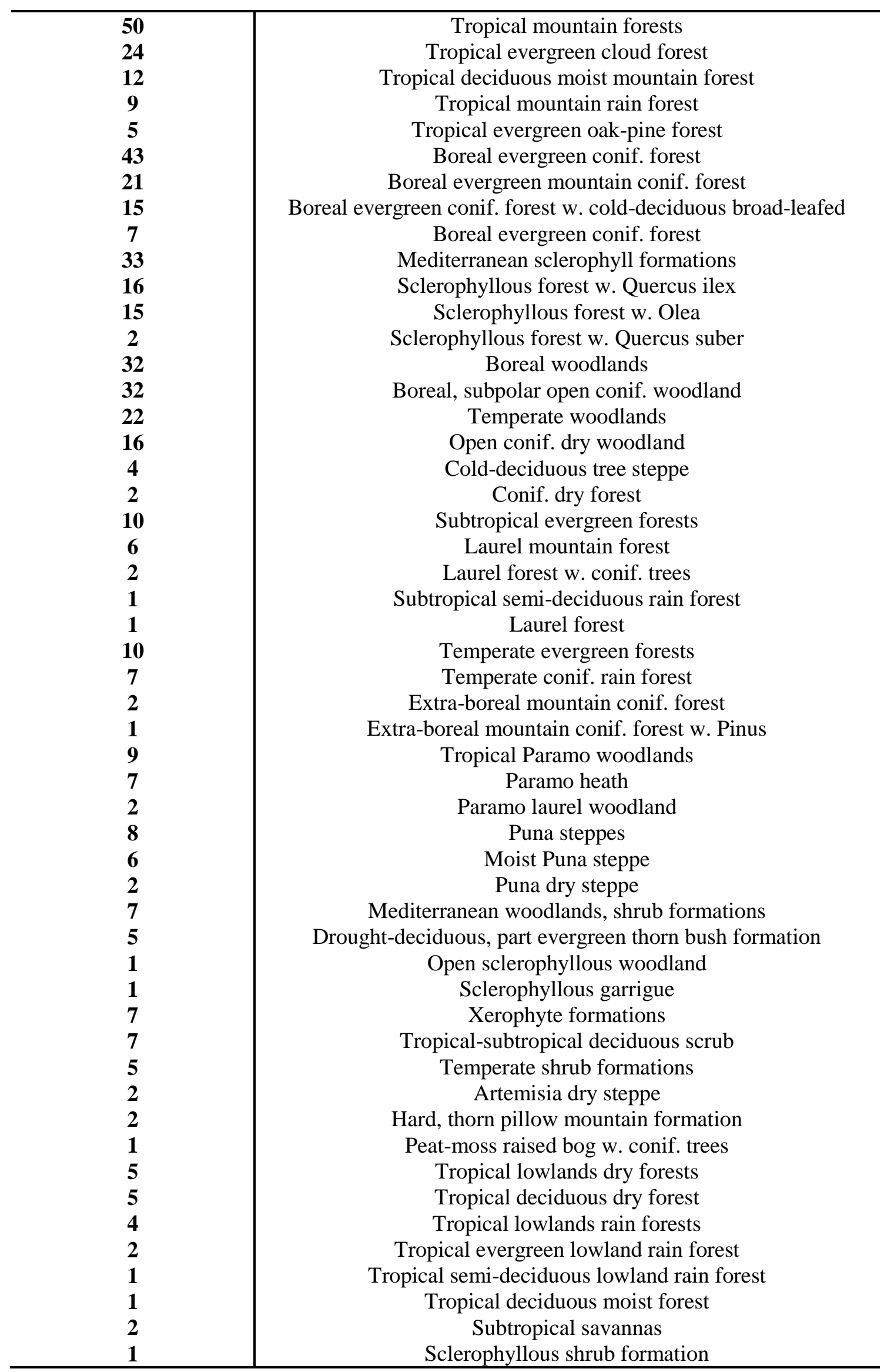




\begin{tabular}{c|c}
\hline $\mathbf{1}$ & Thorn savanna \\
$\mathbf{2}$ & Temperate steppes, grasslands \\
$\mathbf{2}$ & Transitional steppe \\
$\mathbf{1}$ & Subtropical deciduous forests \\
$\mathbf{1}$ & Subtropical cold-deciduous conif. swamp-forest \\
$\mathbf{1}$ & Subtropical halophyte formations \\
$\mathbf{1}$ & Saltings or coastal dune vegetation \\
$\mathbf{1}$ & Tropical savannas \\
$\mathbf{1}$ & Open evergreen savanna woodland \\
$\mathbf{1}$ & Tropical Paramo grasslands \\
$\mathbf{1}$ & Paramo grassland \\
\hline
\end{tabular}

\section{Observed alder distribution}

In Table 4, data about the 49 countries with data records for alder distribution in GBIF database were presented. The 49 countries include 215444 data records with coordinates of the locations, name of the occurred alder species, and the basis of the records for alder occurrences. The countries were ordered after having most data records (i.e. countries with most data records first). The first 20 countries in the Table 4 included the most data records for alder distribution in the GBIF database (see Table 4 column "Rec."). The total number of records in these countries is 208181 of 215444 in 1866 of 4098 half degree grid elements (see Table 4 columns "Rec.", and GBIF 05"). Also, the first 20 countries (14 in Europe, 3 in South America, 2 in Asia, and 1 in Central America,) in the Table 4 include $97 \%$ of the useful data records and the most data density for alder distribution. Each country has over 100 data records, and also 5 data records per half degree GBIF grid cell. Thus, these 20 countries were used for the validation of model prediction about alder distribution. The other 29 countries in the Table 4 included the rest of data records for the alder distribution in GBIF database. Two countries after the middle line the table (US and Canada) have indeed high data records but less data density (records number per grid elements). Therefore, these countries were not considered within the 20 countries. Countries with only one data record in GBIF data base were also not considered and not presented in this paper.

Table 4. Analysis of the data distribution in the GBIF database (GBIF, 2010) which was used for the validation of the ADM model results for 49 countries with data records for alder distribution.

\begin{tabular}{c|c|c|c}
\hline Contry & Nr. of records & Nr. of 0.5 grids & Nr. of GBIF grid \\
\hline UK & 44911 & 146 & 146 \\
NL & 35785 & 17 & 17 \\
BE & 23668 & 17 & 9 \\
SE & 22889 & 321 & 292 \\
FI & 19292 & 253 & 246 \\
FR & 15868 & 261 & 160 \\
NO & 15761 & 271 & 237 \\
DE & 11905 & 191 & 191 \\
IE & 7521 & 43 & 43 \\
ES & 3819 & 212 & 134 \\
JP & 1993 & 163 & 101 \\
\hline
\end{tabular}




\begin{tabular}{|c|c|c|c|}
\hline$\overline{P L}$ & 1898 & 168 & 46 \\
\hline MX & 1362 & 715 & 132 \\
\hline TW & 480 & 14 & 13 \\
\hline AT & 393 & 36 & 28 \\
\hline PT & 169 & 48 & 33 \\
\hline KR & 132 & 40 & 9 \\
\hline $\mathbf{A R}$ & 117 & 1138 & 23 \\
\hline BO & 112 & 365 & 10 \\
\hline EC & 106 & 83 & 19 \\
\hline US & 5166 & 4469 & 1413 \\
\hline CA & 1439 & 7004 & 555 \\
\hline RU & 143 & 14283 & 73 \\
\hline $\mathrm{CN}$ & 80 & 3834 & 3 \\
\hline PE & 50 & 427 & 30 \\
\hline CO & 46 & 377 & 16 \\
\hline PA & 39 & 30 & 2 \\
\hline DK & 38 & 30 & 6 \\
\hline IT & 34 & 145 & 14 \\
\hline CH & 30 & 19 & 10 \\
\hline GT & 27 & 37 & 10 \\
\hline GR & 23 & 61 & 8 \\
\hline $\mathrm{CZ}$ & 23 & 63 & 15 \\
\hline PK & 19 & 326 & 4 \\
\hline NZ & 17 & 135 & 10 \\
\hline $\mathbf{Z A}$ & 14 & 479 & 2 \\
\hline NP & 10 & 53 & 4 \\
\hline TR & 8 & 332 & 4 \\
\hline IN & 8 & 633 & 5 \\
\hline HN & 8 & 42 & 3 \\
\hline $\mathbf{A U}$ & 8 & 2826 & 3 \\
\hline RO & 7 & 111 & 4 \\
\hline VN & 5 & 105 & 2 \\
\hline CL & 5 & 351 & 3 \\
\hline VE & 3 & 304 & 2 \\
\hline BG & 3 & 49 & 2 \\
\hline IL & 2 & 6 & 2 \\
\hline HU & 2 & 45 & 2 \\
\hline GL & 2 & 2770 & 2 \\
\hline
\end{tabular}

Meaning of the columns: (Country) name of the countries; (Rec.) Number of data records for alder distribution in each country (countries with just one data record are not shown); (Grid 0.5) Number of half degree grid elements of the country; (GBIF 0.5) Number of half degree grid elements with data records about the alder distribution. The first 20 countries have in the GBIF grid cells minimum 100 data records and five data records per grid.

\section{Validation of the methods}

Since the 20 countries had the most density for data records about the alder distribution in GBIF database, a statistical analysis between the observed and predicted alder distribution was done in these countries to find out, which method of the four methods ("Clim", "Soil", "Veg", and "All") is more suitable for the modelling of alder distribution. In the Figure 3 the results of the correlation and statistical analyses 
between the observed and predicted number of half degree grid elements with data records about alder distribution were presented. The correlation functions ( $\mathrm{f}(\mathrm{x})$ ), 1:1 lines, correlation coefficients $\left(r^{2}\right)$, index of agreement $(\mathrm{d})$, and mean absolute error $(M A E)$ were also presented in the scatter plots. The actual data of the scatter plots may be found in the Table 5 columns "Grid", "Soil" "Veg", and "All" respectively. The $r^{2}$ values of the correlation analyses ranged between 6 and 84\%. The lowest correlation was found between the observed and "Clim" method based ADM results with $r^{2}=6 \%$. The $\mathrm{d}$ and $M A E$ values of this correlation analysis were 0.36 and 117, respectively (see Figure $3 a$ ). The "Clim" method shown also a large intercept with 117 grid elements. The "Soil" method shown similar correlation with the observed data as the "Clim" method (see Figure 3b). The correlation coefficients $r^{2}$ between this method and observed data were $11 \%$. The value of $\mathrm{d}$ for this method was 0.5 , where the $M A E$ value was 86. The method "Veg" provided a better correlation with the observed data (see Figure $3 c$ ). The values of index of agreement and mean absolute error shown quite good results with $d=0.93$, and $M A E=28$, respectively. But the best correlation coefficient $\left(r^{2}=84 \%\right)$ were found between the observed and "All" method based ADM results (see Figure $3 d$ ). And also the highest d value with 0.96, and the lowest MAE value with 27 were found between the "All" method based ADM and observed data. The intercept of this method was around 27 grid elements. Thus, the correlation analyses shown the best performance between the "All" method based ADM results and the observed data in the high relevant 20 countries. Because of the best $r^{2}, d$, intercept, and MAE values, the "All" method based ADM was used to predict the potential alder distribution areas globally.

The figures in the Appendix give an overview about the statistical analyses between the results of ADM by using each single parameter and observation in the 20 countries, and about the results of "CLIM", "Soil" and "Veg" methods on global scale.

Table 5. Analysis of the data distribution in the GBIF database $(G B I F, 2010)$ which was used for the validation of the ADM model results for 49 countries with data records for alder distribution, and comparison with model results using different constraints besides climate.

\begin{tabular}{c|c|c|c|c|c}
\hline Country & Tot. 0.5 Grid & Clim & Soil & Veg & All \\
\hline UK & 146 & 146 & 138 & 118 & 110 \\
NL & 17 & 17 & 17 & 16 & 16 \\
BE & 9 & 17 & 17 & 17 & 17 \\
SE & 292 & 319 & 319 & 302 & 302 \\
FI & 246 & 247 & 247 & 247 & 247 \\
FR & 160 & 261 & 238 & 256 & 233 \\
NO & 237 & 267 & 267 & 172 & 172 \\
DE & 191 & 191 & 165 & 184 & 162 \\
IE & 43 & 43 & 43 & 38 & 38 \\
ES & 134 & 212 & 206 & 181 & 177 \\
JP & 101 & 163 & 163 & 163 & 163 \\
PL & 46 & 168 & 134 & 168 & 134 \\
MX & 132 & 652 & 329 & 122 & 99 \\
TW & 14 & 14 & 14 & 13 & 13 \\
AT & 28 & 36 & 23 & 34 & 23 \\
\hline
\end{tabular}




\begin{tabular}{l|c|c|c|c|c}
\hline PT & 33 & 48 & 48 & 47 & 47 \\
KR & 9 & 40 & 40 & 40 & 40 \\
AR & 23 & 950 & 746 & 34 & 32 \\
BO & 18 & 259 & 238 & 24 & 24 \\
EC & 19 & 60 & 59 & 18 & 18 \\
US & 1413 & 3925 & 2920 & 2130 & 1912 \\
CA & 555 & 4625 & 3139 & 3403 & 2168 \\
RU & 73 & 10695 & 7952 & 7018 & 4881 \\
CN & 3 & 3070 & 2980 & 1411 & 1379 \\
PE & 30 & 240 & 233 & 53 & 53 \\
CO & 16 & 110 & 105 & 51 & 51 \\
PA & 2 & 5 & 5 & 4 & 4 \\
DK & 6 & 30 & 30 & 30 & 30 \\
IT & 14 & 143 & 134 & 137 & 129 \\
CH & 10 & 19 & 16 & 14 & 11 \\
GT & 10 & 27 & 18 & 14 & 11 \\
GR & 8 & 61 & 61 & 58 & 58 \\
CZ & 15 & 63 & 59 & 63 & 59 \\
PK & 4 & 279 & 237 & 25 & 24 \\
NZ & 10 & 135 & 135 & 7 & 7 \\
ZA & 6 & 461 & 308 & 5 & 5 \\
NP & 4 & 43 & 43 & 3 & 3 \\
TR & 4 & 332 & 325 & 211 & 204 \\
IN & 5 & 1204 & 957 & 187 & 171 \\
HN & 3 & 30 & 26 & 18 & 16 \\
AU & 3 & 2739 & 1773 & 169 & 157 \\
RO & 4 & 111 & 94 & 104 & 93 \\
VN & 2 & 75 & 75 & 29 & 29 \\
CL & 3 & 217 & 206 & 95 & 95 \\
VE & 2 & 192 & 183 & 58 & 58 \\
BG & 1 & 49 & 34 & 48 & 34 \\
IL & 1 & 6 & 6 & 0 & 0 \\
HU & 2 & 45 & 29 & 45 & 29 \\
GL & 3 & 388 & 131 & 0 & 0 \\
\hline
\end{tabular}

Meaning of the columns: (Country) name of the countries; (Tot. 0.5 Grid) Number of half degree grid elements with data records about the alder distribution; (Clim) Number of simulated half degree grid elements with potential alder distribution by using "Clim" method based ADM; (Soil) by using "Soil" method based ADM; (Veg) by using "Veg" method based ADM; (All) by using "All" method based ADM. 

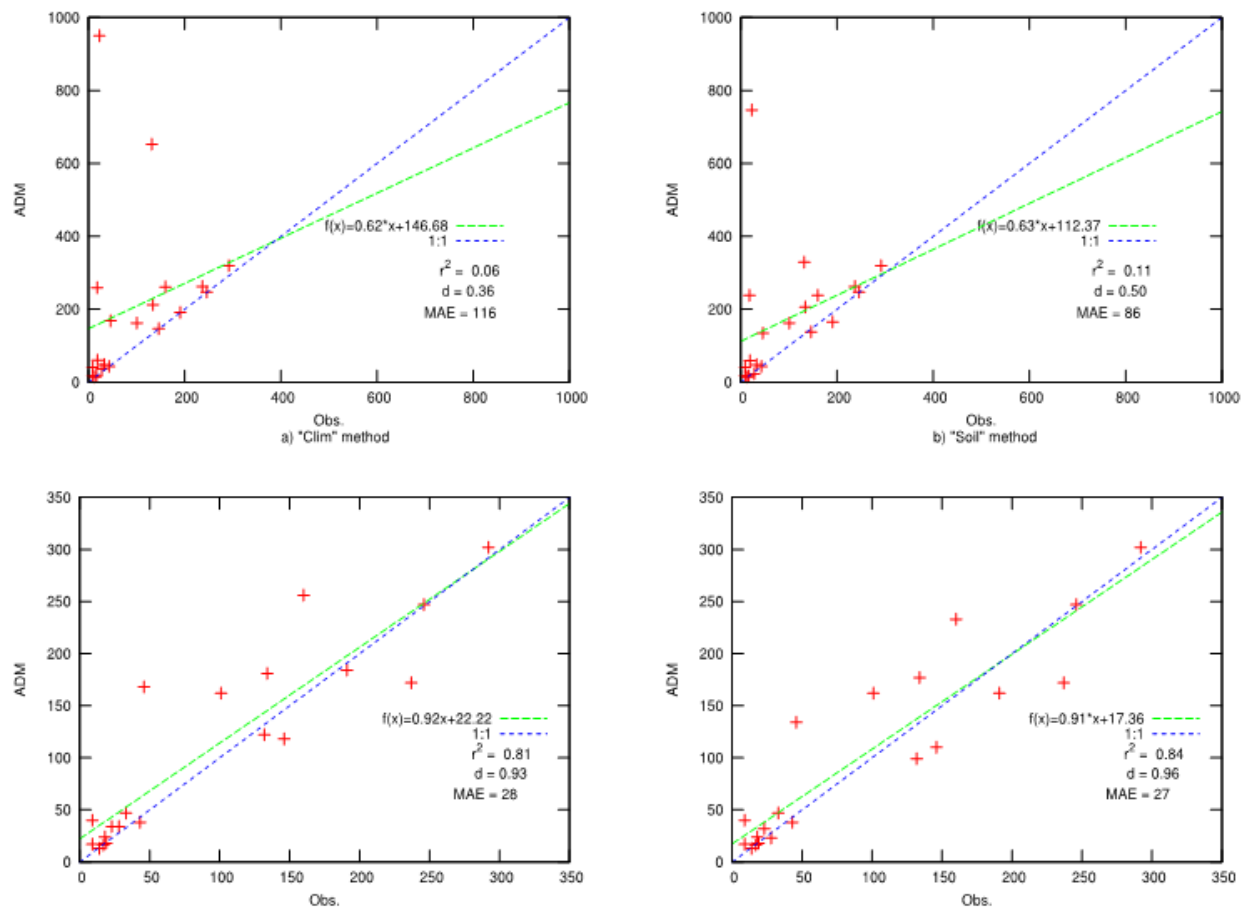

c) "Veg" method

d) "All" mothod

Figure 3. The correlation between the observed and predicted alder distribution in half degree grid elements in 20 countries. Countries from the Table 4 with minimum 100 data records and five data records per each noted half degree grid cell were considered. The regression and $1: 1$ lines are shown along with correlation coefficient $(r)$, index of agreement $(d)$, mean absolute error (MAE).

\section{Global potential alder distribution}

The predicted alder distribution by using "All" method based ADM was shown in Figure 5. It is to see that alder has a large potential distribution areas in Asia and North America. In comparison to the global alder distribution on GBIF map (see Figure 4) the ADM also predicted the potential distribution in several grid elements of South America, Africa, and Australia (see Figure 5). The ADM predicted the alder distribution in 1898 grid elements in the 20 countries where the GBIF database has records in 2066 grid elements (see Table 5 columns "Grid" and "All"). Most of the eliminated grid elements have suitable soil units but not vegetation types for the potential alder distribution in these countries. For example, eliminated grid elements in Norway have the soil unit "Lithosols" and the vegetation type "Mountain vegetation above the tree line". "Lithosols" are the second largest occurred soil units in the 308 grid elements (75 of 308) of the evaluation's grid elements (see Table 2). These grid elements have the suitable climate conditions and soil units but not the vegetation types. Most eliminated grid elements in the 20 countries after using "Soil" and "Veg" methods in ADM were found in Mexico. The dominant soil units in Mexico are "Leptosols", "Regrosols", and "Calcisols" (FAO-Unesco, 1974). Only "Regrosols" were presented in 308 evaluation's grid elements (see Table 2). Also, the dominated vegetation types are "Shrub desert", "Thorn savanna", and the "Open deciduous small leafed" in Mexico. Only the vegetation units "Thorn savanna" were recorded in one of 308 grid elements. In Russia and China, the ADM has shown the potential alder distribution in 67, and 460 
times more grid elements than the GBIF database records. In Russia, grid elements with potential alder distribution have the suitable climate conditions, soil units ("Lithosols" and "Cambisols") as well as the potential natural vegetation groups ("Boreal coniferous forest" and "Boreal woodlands"). These two soil units were recorded in 45 of the 308 evaluation's grid elements (see Table 2) and the vegetation types in 75 of the 308 grid elements (see Table 3). In China, same vegetation types are also the dominant vegetation types in potential distribution areas. However, the mostly coming soil units in those areas are the "Cambisols", "Gleysols" and "Acrisols". The three soil units were found in 121 of 308 grid elements. In comparison to the 20 countries, the US and Canada have also large data records but appreciably low data density per grid elements. The ADM predicted the alder distribution in 499 grid elements more in US and in 1613 in Canada than the GBIF database. In the regions, "Lithosols", "Podzols", "Luvisols", and "Phaozems" are mostly recorded soil units (FAO-Unesco, 1974). The potential natural vegetation groups are mainly "Temperate deciduous forests", and "Mediterranean sclerophyll formations" in the US, "Boreal evergreen conif. forests" in Canada.

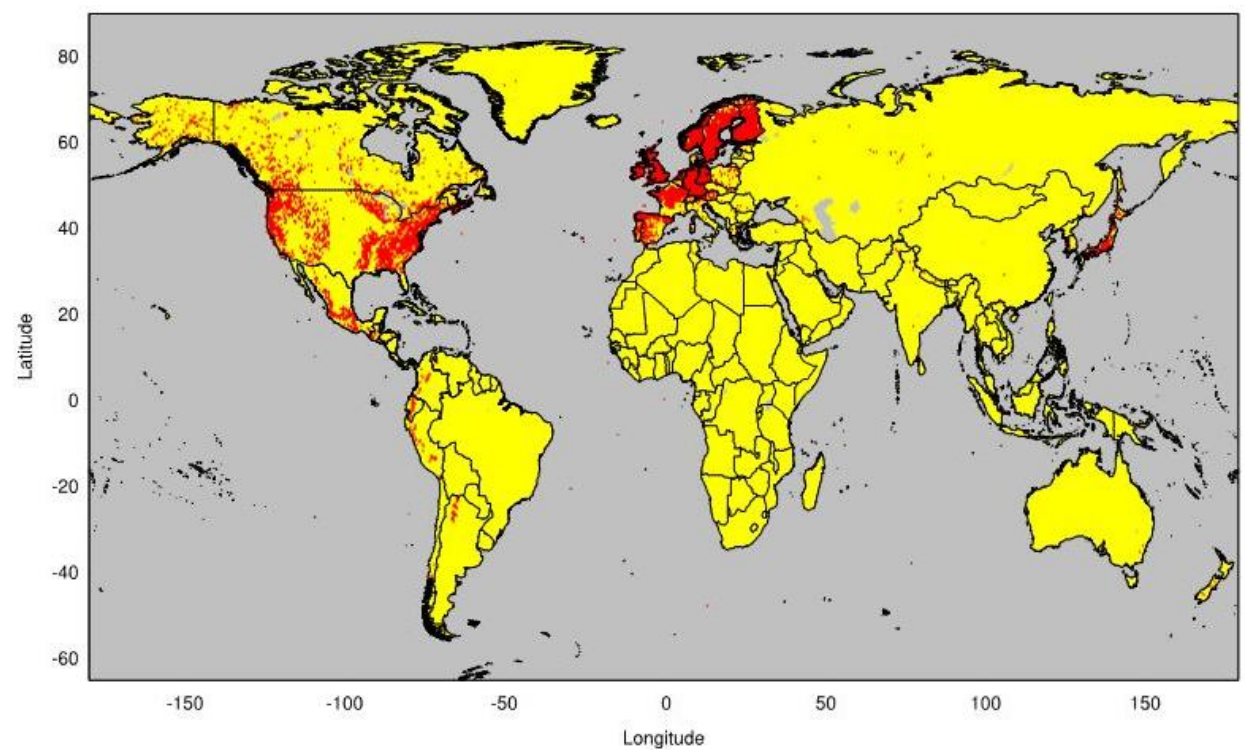

Figure 4. Distribution of alders (red) according to the GBIF database (GBIF, 2010). For the locations with yellow colour there is no data record in the database.

It is generally to see that the "Veg" method eliminated more grid elements than the "Soil" method in 12 of the 20 countries as well as in Russia, in China, and in the US. In France, Germany, Poland, Austria, and Canada more grid elements were eliminated by using the "Soil" method than the "Veg" method.

The results shown that the existence of alders in natural ecosystems is not only depending on climate conditions but also on soil types, and vegetation units. The potential distribution of alders mainly occurs in Northern Hemisphere, but also occurs in quite few locations in south hemisphere with adequate climate conditions, soil types and vegetation units (see Figure 5). Since the alders can fix atmospheric nitrogen, consideration of the nitrogen fixation by alders in their distributional areas in ecosystem and biogeochemical models gives the opportunity to investigate and predict the nitrogen 
fixation impacts on $\mathrm{CO}_{2}$ uptake, and carbon storage in the.

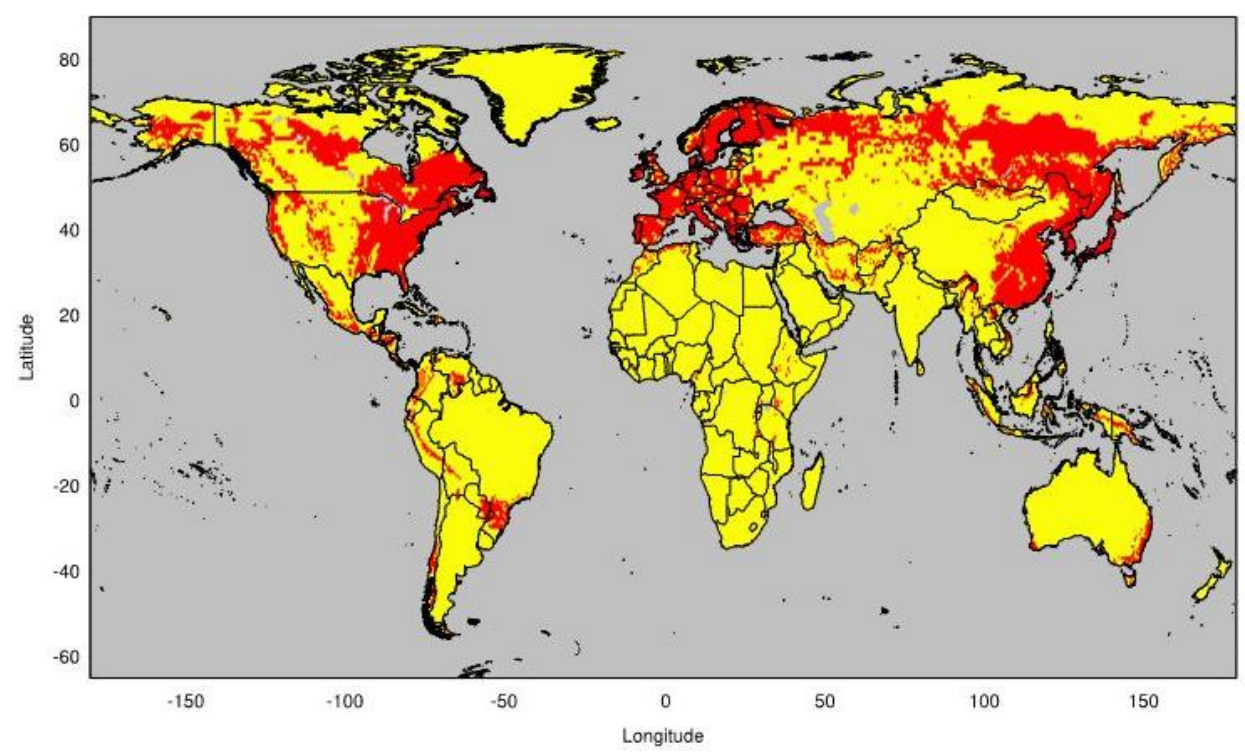

Figure 5. Distribution of grid elements (red) that were identified as potential sites with alder based on the climate functions 1...3 (see also Figure 2). In this version of the model, restriction by vegetation types (see Table 3) and by soil units as found in Table 2 was applied. Yellow: grid elements were not identified as potential distribution area for alder.

\section{Potential distribution and migration of alder in 2100 and 2300}

The absence of alders in the natural ecosystems can also cause an extreme decrease in nitrogen input by $\mathrm{N}_{2}$ fixation of this plants group, and as a result can have gravely consequences for the nitrogen availability in soil of the areas. Therefore, it is important to model the migration of the $\mathrm{N}_{2}$ fixing plants on global scale. To investigate this, the climate data of CCSM4 by driven four IPCC RCP scenarios up to 2300 were used. The rising of atmospheric $\mathrm{CO}_{2}$ has enormous impact on climate change in the future. The using of climate data by driven different RCP scenarios enables to understand the effects of changed climate parameter (i.e. the $\mathrm{T}_{\mathrm{ann}}$ and $\mathrm{P}_{\mathrm{ann}}$ ) by rising $\mathrm{CO}_{2}$ on plant migration (in this study for alders). An increase in $\mathrm{CO}_{2}$ in the atmosphere can also influence plant distribution by e.g. $\mathrm{CO}_{2}$ fertilization, $\mathrm{CO}_{2}$ partial pressure, water use efficiency (Johnson et al., 1993; Collatz et al., 1998). In this study, this type of impacts from $\mathrm{CO}_{2}$ on the alder distribution was not considered.

For this step of the study, it was assumed that the soil unit and the potential natural vegetation groups of a grid element will not be changed in 2100 and 2300. The migration of alder species for those two prediction periods by using the ADM was shown in the Figures 6 and 7. The results show that the alders can extend its distribution northwards. Especially the alder species may be frequently occurring furthermore in Northern Russia and Alaska at all scenarios of the climate models (see the blue areas in Figure 6). Few grid elements in Norway, Finland, the US and Canada may also additionally to be suited for the alder distribution in all scenarios in 2100 . On the other hand, a range of grid elements close to coast in Europe, Southern US and Southern China may not have proper conditions anymore for alder distribution in 2300 (see the red areas in Figure 7). It is further to see that most of the grid elements in Africa, 
Indonesia and middle and south America may be eliminated for the alder distribution by all scenarios of the climate models in 2100 and 2300.

The prediction of potential migration of Alnus spp. by using the climate parameter of four RCP scenarios shown differences on global scale for the two projection periods (2100 and 2300).

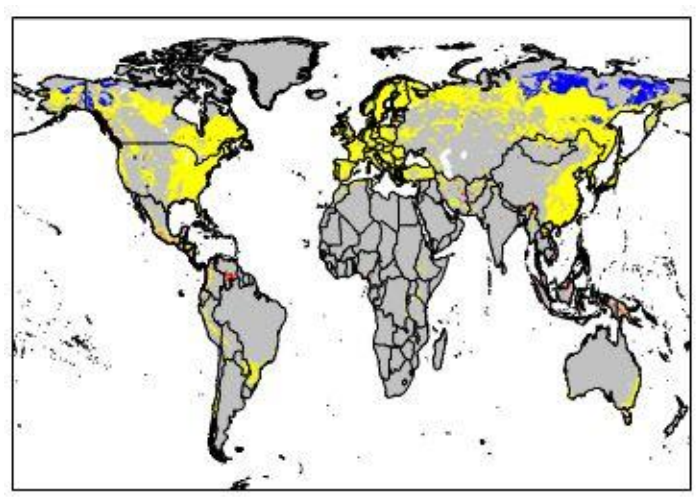

a) RCP2.6

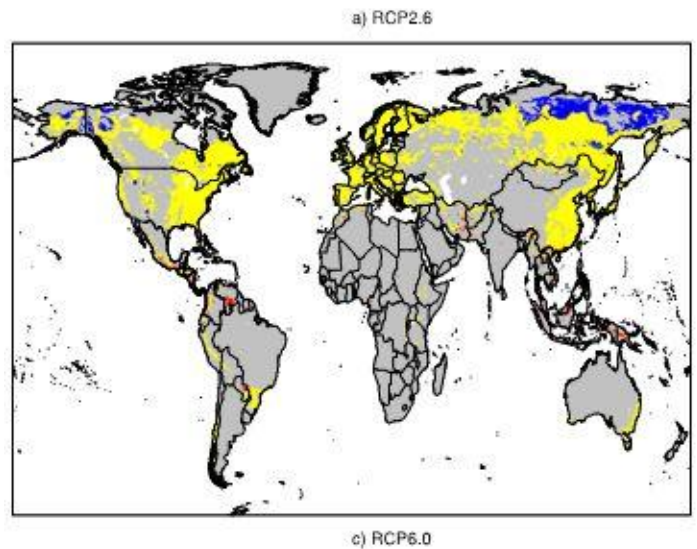

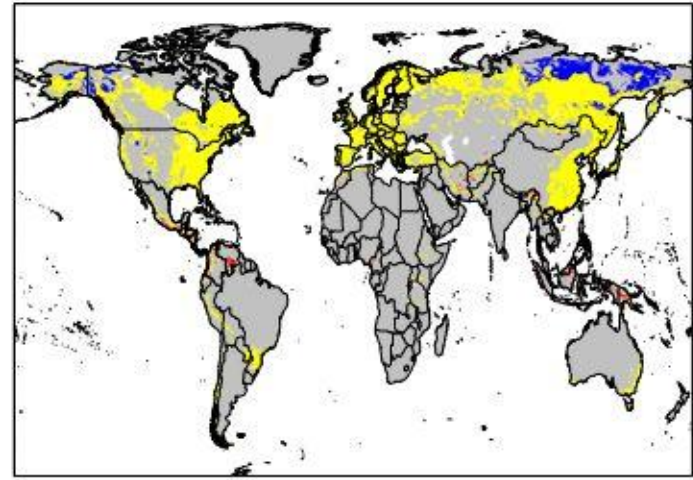

b) $\mathrm{RCP} 4.5$

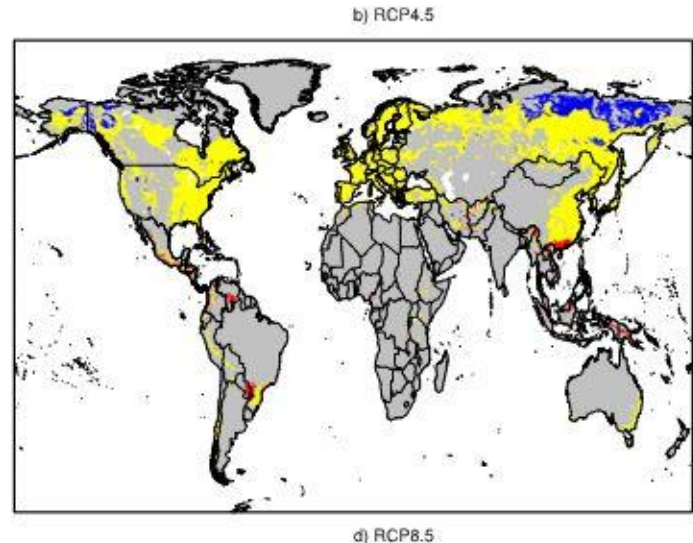

Figure 6. Distribution of grid elements which were identified as potential sites for alder distribution based on the "All" method in ADM by using the climate data from CCSM4 data model which was driven by four RCPs emission scenarios. The colour "yellow" represents the potential distribution areas both present and in 2100, where the colour "red" shows the grid elements with present potential distribution but not in 2100, and also the colour "blue" the grid elements with potential distribution in 2100 but not present.

The results indicated that only a change in two climate parameters (i.e. $\mathrm{T}_{\mathrm{ann}}$ and $\mathrm{P}_{\mathrm{ann}}$ ) can affect the existence and distribution of plants in terrestrial ecosystems in the end of the 21th century. The validation of the methods also pointed out that the changes of soil types and vegetation compositions have enormous influences on the distribution of alders, and this should be considered in modelling studies about plant distribution.

The changes of the climate parameters within the four RCP scenarios have quite similar impacts on the alder distribution at global level in 2100 (see Figure $6 a, b, c$ and d). In 2300, the alder distribution was more affected by the change of the climate parameters in RCP8.5 scenario in the tropical and sub-tropical regions than other three RCP scenarios (see Figure 7-d). 


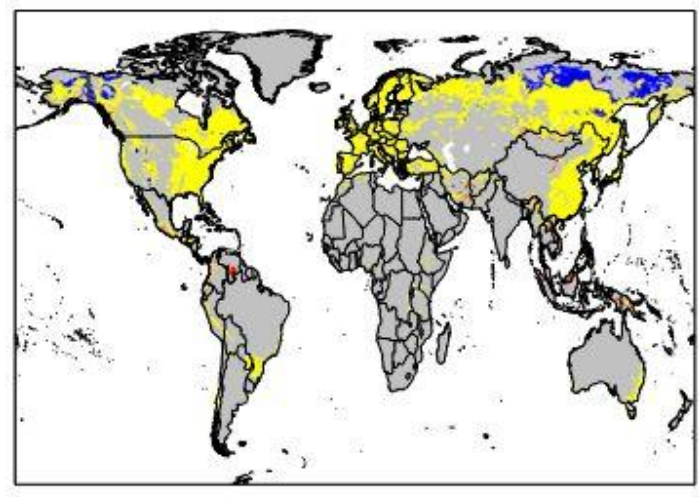

a) $R C P 2.6$

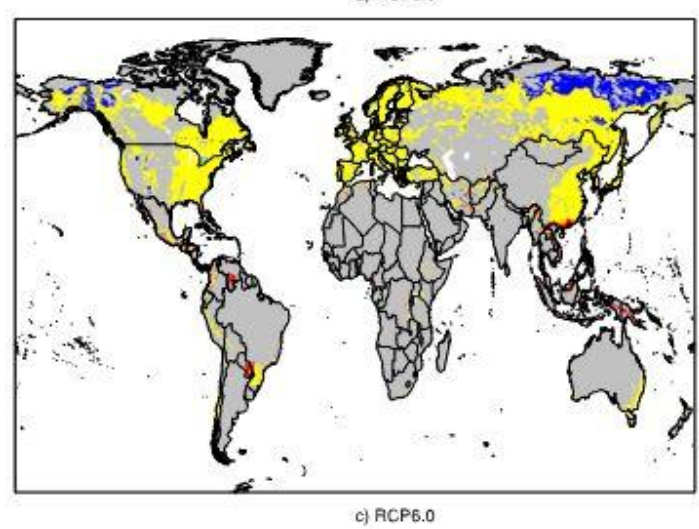

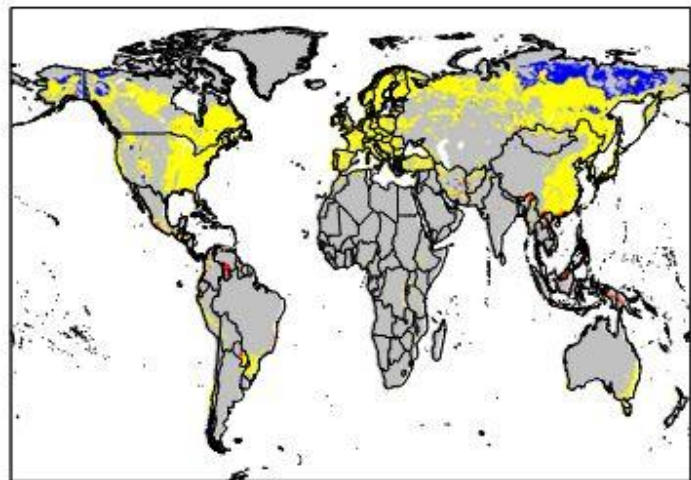

b) RCP 4.5

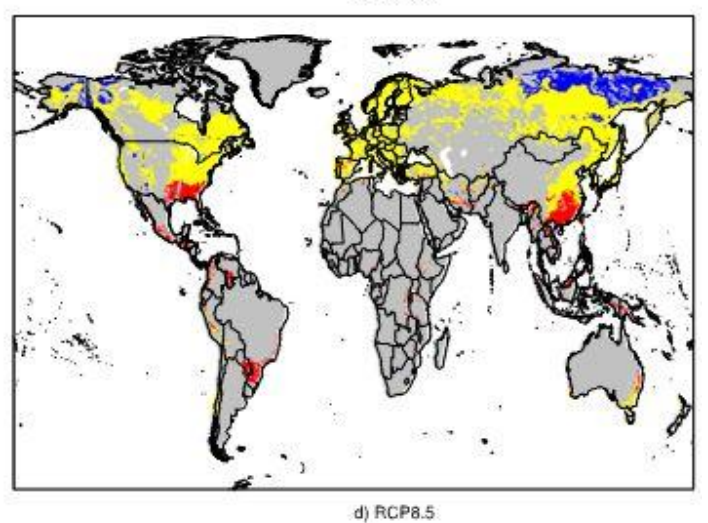

Figure 7. Distribution of grid elements which were identified as potential sites for alder distribution based on the "All" method in ADM by using the climate data from CCSM4 data model which was driven by four RCPs emissions scenarios. The colour "yellow" represents the potential distribution areas both present and in 2100, where the colour "red" shows the grid elements with present potential distribution but not in 2300, and also the colour "blue" the grid elements with potential distribution in 2300 but not present.

\section{Discussion}

The records for the distribution of the world's vegetation types was started by foundations of plant geography ca. 200 years ago (Humboldt, 1807). Also at the beginning of 18th century the scientist started to investigate about the potential effect of climate on plant distribution (Schouw, 1823; Meyen, 1846). Nowadays, numerous models use the climate conditions for the prediction of plant species distribution, and for the modelling of phenological processes of plants (Prentice et al., 1992; Brovkin et al., 1997; Smith et al., 2001; Skjøth et al., 2008; Sakalli and Simpson, 2012). Lantz et al. (2010) investigated the regional temperature impacts on the Alnus viridis subsp. fruticosa (green alder) patch dynamics and plant community (Lantz et al., 2010). They found out that the regional temperature influence the cover, growth, reproduction and age distributions of the green alder. Martínez-Meyer and Peterson (2006) worked on niche models to determine the distribution of eight taxa including $A$. incana and $A$. viridis in North America by using pollen distribution data on present day, and climate data from the Palaeoclimate Modelling Intercomparison Project in Last Glacial Maximum (LGM). They found a similar temperature-precipitation demand for the distribution of $A$. incana (see Figure 3 in the paper). The using of only climate 
parameter in ADM predicted the distribution of all alder species almost in whole Australia, Middle and South Africa, where there is no or very poor record about the distribution of alder (see Appendix Figure 1). Also, the statistical analysis of the "Clim" methods has the poorest correlation in the 20 countries with high density records about the alder distribution. Sykes et al. (1996) developed a bioclimatic model based on climatic geography of the European plants to predict the distribution of northern Europe's dominant trees including the alder species $A$. incana. They used the bioclimatic factors as winter cold tolerance, summer heat and winter cold requirements, and drought tolerance (soil moisture) of the species. Although the bioclimatic model supplied quite good result for the A. incana distribution, it also showed that the distribution of plants was not only depending on the climate factors but also the soil conditions could play a crucial role in the prediction. Like most of the models, the bioclimatic model could be used for prediction of the distribution of specific alder species (not for all species of genus Alnus) on regional scales and needs predefined parameter for each species. Compared to the bioclimatic model, the ADM has the advantage to predict the distribution of all alder species on global and regional scale.

Since, the selected climate factors were alone inadequately to predict the distributions of alder species, and it is well known that the components of each plant community are influenced by soil units, and the alders prefer some specific soil conditions for the occurring in a natural ecosystems (Bean, 1989; Wheeler and Miller, 1990; Claessens et al., 2010), the soil units were used as additionally determinant to the selected climate factors for the modelling of potential alder distribution areas. The addition of the soil units to the "Clim" method showed its impacts mostly in East Europe, Australia, Central and South Africa as well as in North America. But in comparison to the distribution Map from GBIF and the literature data, quite a lot areas were still selected as potential distribution locations for the alder species in that areas (see Figure 4 and Appendix Figure 2). Also, the statistical analysis between the observed and predicted data in the 20 countries resulted a rare correlation (see Figure $3 b)$.

In the natural ecosystems plants are living in a species compositions which are called plant communities (Schmithüsen, 1968). Each plant species belongs to a community and is related to other species of the community (Breckle, 2002). Therefore, the relations of the species in plant communities, and the using of the relations were quite important in modelling of distribution of plant species. Woodward and Williams (1987) investigated the effect of climate on plant distribution on global and local scales. Their predictions of the distribution of the vegetation were based on temperature, precipitation and annual water balance of the distribution areas. They enhanced also that the climate conditions are not sufficiently for the modelling of the distribution of vegetation or species, and in such modelling studies, the population dynamics (plant-plant interactions) should be also considered. Therefore, the potential natural vegetation groups after Schmithüsen (1976) were used as additional determinant to the "Clim method" for the prediction of the potential distribution areas for alder species. Although the statistical of the results in the 20 countries showed quite good correlation with the observed data from the GBIF database (see Figure 3c), on the global scale, the comparing of the results (see Appendix Figure 3) with the distribution map from GBIF database (see Figure 4) presented noticeable differences in East Europe, in Canada, Southeast Australia and America. In some local studies, the scientist tried to find out the interspecific relationships between plant species in plant communities, and the 
relationships between the dispersal of the species and the environmental, biological, and geological factors. Jones et al. (2008); Flinn et al. (2010); Aiba et al. (2012); Lin et al. (2013) pointed out that plant dispersal is not depending on environmental factors. They found a poor correlation between the environmental factors and plant dispersal. On the other hand, they also did not use the combination of annual average temperature and sum of the precipitation as determinant in their studies. The used parameters (Wind, NO3, soil humus content etc.) were also dynamic parameters, which can have strong seasonality. The ADM considered the average of 30 years of the climate data (19611990). That eliminated the uncertainties regarding to the dynamic seasonality of climate parameters.

Although, only $6 \%$ of the alder distribution can be explained by using the climate data in this study (see Figure 3), results of this study showed that the distribution of plant species was not only depending on the climate factors but also on the soil types, and the vegetation units should be considered together. The additions of soil units and potential natural vegetation groups to the "Clim" method pointed out that both determinants can influence the prediction of the potential distribution areas of alder species in different regions. Therefore, all determinants were merged in one method for the modelling of the potential distribution areas of alder species. The "All" method of the ADM shows a new kind of modelling issue for plant distribution. The statistical analysis of the "All" method results showed quite good correlation and the best value of index of agreement as well as the lowest MAE (see Figure 3d). The predicted potential distribution areas for alder species using the "All" method was presented in the Figure 5. In comparison to the potential distribution maps of the "Clim", "Soil" and "Veg" methods, there is a further improvement of the predicted distribution especially in Central and Eastern Asia, and in America. But there are still differences between the observed and predicted distribution areas in Asia, Africa, Southeast Australia and America. It is well known that alder grows well on acid soils and its growth can be restricted under the alkaline or neutral conditions. "Lithosols" are typical soil unit in temperate climate zone under coniferous forests, and the "Camsbisols" are well represented in boreal and temperate regions. The two soil units are well represented in Russia and known as acid soils. Suitable climate conditions and vegetation groups make possible to distribute the alders in large areas in Russia. Murai (1968) published the potential distribution areas of alder species (A. viridis and A. crispa) in Russia in a vegetation map (Murai, 1968). It shows that the distribution of $A$. viridis and A. crispa stretches in most vegetation zones of Russia. Also, Kajba and Gracan (2003) illustrated a map for the distribution of A. glutinosa in Europe (Kajba and Gracan, 2003). It showed that $A$. glutinosa also distribute in several locations in Russia. These maps confirm that the results of ADM prediction for Russia are acceptable. Furthermore, the GBIF database does not indicate the absence of alders. Therefore, grid elements with no data records may indicate either the absence of alders or the absence of observations. Because of the suitable climate, soil, and vegetation conditions, it is highly probable that alders can distribute in these areas (Czerepanov, 1995). Globally, ADM may provide better results for the distribution of this genus. The discussion of this results also shows the importance to improve the GBIF database for validation of such model results. In China, the alder distribution was recorded in only three grid elements (see Table 4). But "All" method based ADM predicted the distribution in 1376 grid elements more than the GBIF database. Likewise, it is well known that $A$. nepalensiss distributes in moist, cool, subtropical monsoon climates with a dry season of 4-8 months in Guangxi, 
Guizhou, SW Sichuan, Xizang, Yunnan of China (Furlow, 1979; Sharma and Ambasht, 1991; Chen, 1994; Jackson, 1994; Dorthe, 2000; Chen and Li, 2004). It also shows that the prediction of ADM for alder distribution is more reliable than GBIF database in China. Furthermore, some regions in Central Africa and southeast Australia still remain. The regions in Central Africa are known to be suitable for alder cultivation, however, no natural occurrence of alders is recorded in the areas. Such plantations of alder species are also recorded in African highlands (Wajja-Musukwe et al., 2008; Muthuri et al., 2009; Siriri et al, 2013). Niang et al. (1996) published data about the adapted alder species (A. acuminata $\mathrm{HBK}$ ) to the highlands of Rwanda in Central Africa. The average annual rainfall is $1500 \mathrm{~mm}$ and the annual mean temperature is $14.6{ }^{\circ} \mathrm{C}$ in the study site. The values of the climate parameters are in the climate field (see Figure 2). The dominant soil unit is a "Podzols" and the vegetation group is a "tropical forests of higher elevation". Both the soil unit and the vegetation type are presented in the 308 evaluation's data (see Tables 2 and 3). This result shows that the alder species can well distribute in some areas of Central Africa, and the prediction of ADM can be right in Central Africa. In southeast Australia, 8 records in totally 3 grid elements were recorded in GBIF data base (see Table 4). But the model results shown that alders potentially can distribute in 157 grid elements in this area. The $\mathrm{T}_{\mathrm{ann}}$ and $\mathrm{P}_{\mathrm{ann}}$ values in the regions range $8-15^{\circ} \mathrm{C}$ and $500-1100 \mathrm{~mm}$, respectively. The dominant vegetation unit is "Laurel mountain forests" as well as "Laurel forest w. conf. trees", and "Luvisols" are the most recorded soil types in southeast Australia. The values of the climate parameter in the 157 grid elements are found in the climate matrix field in the Figure 2 as well as the vegetation units and the soil types are appropriate units and types for a potential alder distribution. Therefore, it is quite possible that the alders can have larger distribution than as recorded in GBIF database for southeast Australia. Hnatiuk (1990) also recorded an alder species (A. glutinosa) in Australia, and indicated that four related species have also naturalized in Australia. But, there is no information about the distribution locations of the alders in his study.

A visible and an important difference between the predicted and observed alder distribution is to see in South American lowland and Araucaria forests in Brazil and Paraguay (see Figure 5). The ADM show the potential alder distribution in 168 of 1653 grid elements in Brazil and in 40 of 143 in Paraguay where the GBIF database does not include data records about the alder distribution. But, Ledru et al. (2007) and Behring (1997) published data about the pollen distribution of some alder species in Araucaria forests in South Brazil. Also, Marchant et al. (2002) presented data about pollen distribution of alder in several Middle and South American countries. They found alder pollen in gallery forests and forests with Quercus-Pinus species. These pollen data show that alder species have distributed in the regions of South America with suitable climate conditions, soil units and vegetation groups. But, data records about current occurrence of alders with coordinate data are still needed in the regions for a reliable comparison of the model results.

The pollen records of the alder species in some areas, where the alders currently do not represent show that the alders have potential for migration. Van Minnen et al. (2000) reported that the alders need between 50 and 200 years to change its distribution areas due to the climate change. The migration of nitrogen fixers will certainly influence the natural nitrogen fixation in the ecosystems. Esser et al. (2011) showed the effect of nitrogen fixation on carbon biogeochemical cycle by switching off and on the nitrogen fixation fluxes in the nitrogen carbon interaction model (NCIM) (see model scenarios in 
Esser et al., 2011). They presented a three times carbon storage with a nitrogen availability than without in the biosphere. Since a migration of $\mathrm{N}_{2}$-fixing plants changes the amount of available nitrogen in soil for soil microorganisms and plants, as important $\mathrm{N}_{2}$-fixing group, the investigation of the spatial and temporal alder migration is quite important.

The using climate parameters from different climate models and scenarios gives important indications of climate change effects on alder distribution and migration in the future. As it presented in Figure 1, CCSM4 provides variously $\mathrm{T}_{\mathrm{ann}}$ and $\mathrm{P}_{\mathrm{ann}}$ by using four IPCC RCP scenarios. There is quite difference between the values of the $T_{\text {ann }}$ as well as $\mathrm{P}_{\text {ann }}$ of the models, and the difference between the four scenarios of the models are quite large (ca. $16{ }^{\circ} \mathrm{C}$ for $\mathrm{T}_{\mathrm{ann}}$ and ca. $250 \mathrm{~mm}$ for $\mathrm{P}_{\mathrm{ann}}$ in 2300). Though, the effects of the climate parameter of the models, and scenarios on the alder distribution on global scale are quite similar (see Figure 7). There is unfortunately no similar study to compare the results of the ADM by using values of the climate parameter from the four IPCC RCP scenarios of a GCM model. Therefore, it is assumed that the prediction of the potential alder distribution (migration) in the future is quite reasonable according to the results of this study.

\section{Conclusion}

In this paper, a new methodology for predicting of potential distribution of alder species on global scale is presented. The new methodology of ADM gives the scientist the possibility to understand the climatological and ecological requirements of alder species to distribute in natural areas and the opportunity to implement a simple method to predict the potential distribution locations of the alder species on each resolution. The using simplified approaches as in "All" method of the model allows the scientist to understand the functionality of plant distribution by considering the environmental and geological factors. The model shows that combine effect of the all three parameters (i.e. climate, soil, vegetation) is the predictor for the identification of potential habitats for the alders. Climate alone may not predict the range of alders correctly. By using soil units and potential natural vegetation groups as additional predictors, the identification of potential alder sites is much closer to the presented distribution map of GBIF database. In this paper, the temporal and spatial change of alder distribution was modeled by using the climate variables from the CCSM4, which was driven with four RCP scenarios (RCP2.6, RCP4.5, RCP6.0, RCP8.5) up to 2300. The using of climate variables should give an overview of the sensitivity of the methodology for modelling of plant distribution according to climate models. The using of the climate variables of four RCP scenarios in this study allows the scientists the investigation of the sensitivity of plant distribution by considering the different emission scenarios on global scale up to 2100 and 2300, respectively. Because of the missing dynamic vegetation data and dynamic soil unit data for 2300 , only the climate parameters were dynamically changed in the ADM for predicting the potential distribution of alder species in 2300 . The results of the ADM show that numerous regions in Northern Hemisphere will get the suitable conditions for the migration of alder species. But also, a lot of grid elements in Southern Hemisphere will not be suitable for alder occurrence.

Although clearly dynamic datasets for soil units and vegetation groups are needed for a testimonial evidence, the simple requirements of the ADM methodology might make it suitable for use in other biogeochemical models and other modelling systems. 


\section{REFERENCES}

[1] Aiba, H., Takafumi, H., Hiura, T. (2012): Interspecific differences in determinants plant species distribution and relationships with functional traits. - J. Ecol. 100: 950-957, doi:10.1111/j.1365-2745.2012.01959.x.

[2] Bartlein, P. J., Whitlock, C., Shafer, S. L. (1997): Future climate in the Yellowstone National Park Region and its potential impact on vegetation. - Conserv. Biol. 11: 782792.

[3] Bean, W. (1989): Trees and Shrubs Hardy in Great Britain, Vol. 1-4 and Supplement. A classic with a wealth of information on plants, but poor on pictures. - Royal Botanic Garden, London, Great Britain.

[4] Behling, H. (1997): Late quaternary cegetation, climate and fire history of the Araucaria Forest and Campos Region from Serra Campos Gerais, Parana State (South Brazil). Rev. Palaeobot. Palyno. 97: 109-121.

[5] Binkley, D., Cromack, K., and Baker, D. D. (1994): Nitrogen fixation by red alder: biology, rates, and controls. - In: Hibbs, D. E., DeBell, D. S., Tarrant, R. F (eds.) The Biology and Management of Red Alder. Oregon State University Press, Corvallis, 57-72.

[6] Breckle, S. W. (2002): Walter's Vegetation of the Earth. The Ecological Systems of the Geo-Biosphere, (4th edn.). - Springer-Verlag, Berlin, Heidelberg, New York, 87.

[7] Brooker, R. W. (2006): Plant-plant interactions and environmental change. - New Phytol. 171: 271-284. doi:10.1111/j.1469-8137.2006.01752.x.

[8] Brovkin, V., Ganopolski, A., Svirezhev, Y. (1997): A continuous climate-vegetation classification for use in climate-biosphere studies. - Ecol. Model. 101: 201-261.

[9] Brown, J. H. (1984): On the relationship between abundance and distribution of species. Am. Nat. 124: 255-279.

[10] Chen, Z., Li, J. (1994): Phylogenetics and biogeography of Alnus (Betulaceae) inferred from sequences of nuclear ribosomal DNA its region. - Int. J. Plant Sci. 165: 325-335.

[11] Chen, Z.-D. (1994): Phylogeny and phytogeography of the betulaceae. - Acta Phytotaxon. Sin. 32: 1-31.

[12] Claessens, H., Oosterbaan, A., Savill, P., Rondeux, J. (2010): A review of the characteristics of Black Alder (Alnus glutinosa (L.) Gaertn.) and their implications for silvicultural practices. - Forestry 83: 163-175.

[13] Collatz, G. J., Berry, J. A., Clark, J. S. (1998): Effects of climate and atmospheric $\mathrm{CO}_{2}$ partial pressure on the global distribution of $\mathrm{C} 4$ grasses: present, past, and future. Oecologia 114: 441-454.

[14] Cramer, W., Leemans, R. (1991): The IIASA Database for Mean Monthly Values of Temperature, Precipitation and Cloudiness of a Global Terrestrial Grid. - International Institute for Applied Systems Analysis (IIASA), RR-91-18, Laxenburg, Austria.

[15] Czerepanov, S. K. (1995): Vascular Plants of Russia and Adjacent States (former USSR). - ISBN-10: 0521450063, New York, USA.

[16] Dai, Y. M., He, X. Y., Zhang, Z. Z. (2004): Characterization of genetic diversity of Frankia strains in nodules of Alnus nepalensis D. Don from the Hengduan Mountains on the basis of PCR-RFLP analysis of the nifD-nifK IGS. - Plant Soil 267: 207-212.

[17] Davis, M., Zabinski, C. (1992): Changes in geographical range resulting from greenhouse warming: effects on biodiversity in forests. - In: Peters, R. L., Lovejoy, T. E. (eds.) Global Warming and Biological Diversity. Yale University Press, New Haven (CT), 297308.

[18] Dorthe, J. (2000): Alnus nepalensis. - Danida Forest Seed Centre, Humlebaek, Denmark, 2.

[19] Dukes, J. S., Mooney, H. A. (1999): Does global change increase the success of biological invaders? - Trends Ecol. Evol. 14: 135-139.

[20] eFloras (2010): Missouri Botanical Garden, St. Louis, MO, Harvard University Herbaria, Cambridge, MA. - http://www.efloras.org (last access: 4 December 2010). 
[21] Esser, G. (2010): Nitrogen Carbon Interaction Model - NCIM, Documentation: Model Version 3.00. - Mitteilungen aus dem Institut für Pflanzenökologie der Justus-LiebigUniversitat Giessen, Volume 5, 57 (in English).

[22] Esser, G., Kattge, J., Sakalli, A. (2011): Feedback of carbon and nitrogen cycles enhances carbon sequestration in the terrestrial biosphere. - Global Change Biology 17: 819-842.

[23] FAO-Unesco (1974): Soil Map of the World, vol. I-X. - Paris.

[24] Flinn, K. M., Gouhier, T. C., Lechowicz, M. J., Waterway, M. J. (2010): The role of dispersal in shaping plant community composition of wetlands within and old growth forest. - Journal of Ecology 98: 1292-1299. doi:10.1111/j.1365-2745.2010.01708x.

[25] Furlow, J. J. (1979): The Systematics of the American species of Alnus (Betulaceae). Rhodora 81: 1-121.

[26] Galloway, J. N., Cowling, E. B. (2002): Reactive nitrogen and the world: 200 years of change. - Ambio 31: 64-71.

[27] Galloway, J. N., Dentener, F. J., Capone, D. G., Boyer, E. W., Howarth, R. W., Seitzinger, S. P., Asner, G. P., Cleveland, C. C., Green, P. A., Holland, E. A., Karl, D. M., Michaels, A. F., Porter, J. H., Townsend, A. R., Vöosmarty, C. J. (2004): Nitrogen cycles: past, present, and future. - Biogeochemistry 70: 153-226.

[28] GBIF (2010): Bioiversity occurrence data provided by: Botanical Society of the British Isles - Vascular Plants Database, Environment and Heritage Service - EHS Species Datasets, Plants (GBIF-SE: Artdatenbanken), Vascular Plants, Field notes, Oslo (O), Observations du Conservatoire Botanique National du Bassin Parisien, Bundesamt für Naturschutz/NetzIrk Phytodiversitat Deutschland etc. 102.066 records, GBIF Data Portal, available at: http://www.gbif.net, (last access: 4 December 2010).

[29] GTOPO30 (2010): Global Digital Elevation Model (GTOPO30) - The U.S. Geological Survey, EROS Data Center Distributed Active Archive Center (EDC DAAC), Redlands, California, USA. [30] Hagenstein, R. Rickets, T. (2001):Beringia $\quad$ lowland
http://www.worldwildlife.org/wildworld/profiles/terrestrial/na/na1106 fundra. access: on 14 October 2004.

[31] Harrington, C. A. (1991): Alnus rubra Bong.: Red Alder. - In: Burns, R. M. and Honkala, B. H. (eds.) Silvics of North America: Volume 2. Hardwoods, USDA Forest Service, Washington D. C., 654 116-123.

[32] Harrington, C. A., Zasada, J. C., Allen, E. A. (1994): Biology of Red Alder (Alnus rubra Bong).- In: Hibbs, D. E., DeBell, D. S., and Tarrant, R. E (eds.) The Biology and Management of Red Alder. Oregon Sate University Press, Corvallis, OR, 3-22.

[33] Hnatiuk, R. J. (1990): Census of Australian Vascular Plants, Australian Flora and Fauna Series No. 11. - Bureau of Flora and Fauna, Australian Government Publishing Service, Canberra.

[34] Humboldt, von A. (1807): Ideen zu einer Geographie der Pflanzen nebst einem Naturgemälde der Tropenländer. - Tübingen, Dem Erstern, Cotta (in German).

[35] Iverson, L. R., Prasad, A. M. (2002): Potential redistribution of tree species habitat under five climate change scenarios in the eastern US. - Forest Ecology Management 155: 205222.

[36] Jackson, J. K. (1994): Manual of Afforestation in Nepal. - Nepal-United Kingdom Forestry Research Project, Forest Survey and Research Office, Dept. of Forest, UK, Kathmandu, Nepal, 402.

[37] Johnson, H. B., Polley, H. W., Mayeux, H. S. (1993): Increasing $\mathrm{CO}_{2}$ and plant-plant interactions: effects on natural vegetation. - Vegetatio 104/105: 157-170.

[38] Jones, M. M., Tuomisto, H., Borcard, D., Legendre, P., Clark, D. B., Olivas, P. C. (2008): Explaining variation in tropical plant community composition: influence of environmental and spatial data quality. - Oecologia 155: 593-604. doi:10.1007/s00442007-0923-8.

[39] Kajba, D., Gracan, J. (2003): EUFORGEN Technical Guidelines for genetic conservation 
and use for Black Alder (Alnus glutinosa). - International Plant Genetic Resources Institute, Rome, Italy, 6.

[40] Kamruzzahan, S. (2003): Is Alnus viridis a glacial relict in the Black Forest? - InauguralDissertation zur Erlangung der Doktorwürde der Fakultat für Biologie der AlbertLudwigs-Universität Freiburg im Breisgau.

[41] Kurz, W. A., Apps, M. J. (1999): A 70 year retrospective analysis of carbon fluxes in the Canadian forest sector. - Ecological Application 9: 526-547.

[42] Lantz, T. C., Gergel, S. E., Henry, G. H. R. (2010): Response of green alder (Alnus viridis subsp. fruticosa) patch dynamics and plant community composition to fire and regional temperature in north-western Canada. - Journal of Biogeography 37: 1597-1610.

[43] Ledru, M.-P., Salatino, M. L. F., Ceccantini, G., Salatino, A., Pinheiro, F., Pintaud, J.-C. (2007): Regional assessment of the impact of climatic change on the distribution of a tropical conifer in the lowlands of South America. - Diversity and Distribution 13: 761771, doi:10.1111/j.1472-4642.2007.00389.x.

[44] Lepper, M. G., Fleschner, M. (1997): Nitrogen fixation by Cercocarpus iedifolius (Rosaceae) in pioneer habitats. - Oecologia 27: 333-338.

[45] Li, P.-C., Skvortsov, A. K. (1999): Betulaceae. - In: Wu, Z. Y., Raven, P. H. (eds.) Flora of China, vol. 4. Science Press, Beijing and Missouri Botanical Garden Press, St. Louis. 301-304.

[46] Lin, G., Stralberg, D., Gong, G., Huang, Z., Ye, W., Wu, L. (2013): Separating the effects of environment and space on tree species distribution: from population to community. PloS ONE 8: 1-10. doi:10.1371/journal.pone.0056171.

[47] Marchant, R., Almeida, L., Behling, H., Berrio, J. C., Bush, M., Cleef, A., Duivenvoorden, J., Kappelle, M., De Oliveira, P., de Oliveira, A. T., Lozano-Garcia, S., Hooghiemstra, H., Ledru, M. P., Ludlow-Wiechers, B., Markgraf, V., Mancini, V., Paez, M., Prieto, A., Rangel, O., Salgado-Labouriau, M. L. (2002): Distribution and ecology of parent taxa of pollen lodged within the Latin American Pollen Database. - Rev. Palaeobot. Palyno. 121: 1-75.

[48] Martínez-Meyer, E., Peterson, A. (2006): Conservatism of ecological niche characteristics in North American plant species over the Pleistocene-to-Recent transition. - Journal of Biogeography 33: 1779-1789.

[49] Meyen, F. J. F. (1846): Outlines of the Geography of Plants: with Particular Enquiries Concerning the Native Country, the Culture, and the Uses of the Principal Cultivated Plants on the which the Prosperity of Nations in Based. - Ray Society, London.

[50] Min, B. M., Kim, J.-H. (1999): Plant distribution in relation to soil properties of reclaimed lands on the Ist Coast Korea, - J. Plant Biol.: 42: 279-286.

[51] Mitchell, T. D., Jones, D.: An improved method of constructing a database of monthly climate observations and associated high-resolution grids. - International Journal of Climatology 25: 693-712.

[52] Müller, M. J. (1982): Selected Climatic Data for a Global Set of Standard Stations for Vegetation Science, Tasks for Vegetation Science, 5. - Junk Publishers, The Hague.

[53] Murai, S. (1968): Biology of Alder, USDA Portland. - Oregon, 23-36.

[54] Muthuri, C. W., Ong, C. K., Craigon, J., Mati, B. M., Ngumi, V. W., Black, C. R. (2009): Gas exchange and water use efficiency of trees and maize in agroforestry systems in semi-arid Kenya. - Agricultural Ecosystem and Environment 129: 497-507. doi:10.1016/j.agee.2008.11.001.

[55] Myrold, D. D., Huss-Dannel, K. (1994): Population dynamics of alder-invective Frankia in a forest soil with and without host trees. - Soil Biology and Biochemistry 26: 533-540.

[56] NACS (1980): Advisory Committee on Technology Innovation Firewood Crops: Shrub and Tree Species for Energy Production, vol. 1. - National Academy of Sciences, Washington, D. C., PB 81-150716 (NTIS).

[57] Nasir, Y. J. (1975): Flora of Pakistan. - Missouri Botanical Garden Press, St. Louis, MO.

[58] Niang, A., UgiziI, J., Styger, E., Ghamanyi, A. (1996): Forage potential of eight woody 
species: intake and growth rates of local young goats in the highland region of Rwanda. Agroforest. Syst. 34: 171-178.

[59] Overpeck, J. T., Bartlein, P. J., Webb III, T. (1991): Potential magnitude of future vegetation change in Eastern North America: comparisons with the past. - Science 254: 692-695.

[60] Prentice, I. C., Cramer, W., Harrison, S. P., Leemans, R., Monserud, R. A., Solomon, A. M. (1992): A global biome model based on Plant Physiol. and dominance, soil properties and climate. - Journal of Biogeography 19: 117-134.

[61] Pyke, D. A., Archer, S. (1991): Plant-plant interactions affecting plant establishment and persistence on revegetated rangeland. - Journal of Range Management 44: 550-557.

[62] Quézel, P., Médail, F., Loisel, R., Barbero, M. (1999): Biodiversity and conservation of forest species in the Mediterranean basin, FAO. http://www.fao.org/docrep/x1880e/x1880e05.htm (last access: 10 January 2009).

[63] Racine, C., Lichvar, R., Duffy, M. (2001): An inventory of the vascular flora of Fort Greely, interior Alaska, Technical Report No. A172983. - U.S. Army Engineer Research and Development Center, Cold Regions Research and Engineering Laboratory, Hanover, NH. 51.

[64] Reese, C. A. (2003): Pollen dispersal and deposition in the high central Andes. - South America, Dissertation to the Graduate Faculty of the Louisiana State University and Agricultural and Mechanical College in partial fulfillment of the requirements for the degree of Doctor of Philosophy in the Department of Geography and Anthropology, Baton Rouge, USA.

[65] Reich, P. B., Hobbie, S. E., Lee, T., Ellsworth, D. S., Ist, J. B., Tilman, D. (2006): Nitrogen limitation constrains sustainability of ecosystem response to $\mathrm{CO}_{2}$. - Nature 440: 922-925. doi:10.1038/nature04486.

[66] Saikia, S. P., Jain, V. (2007): Biological nitrogen fixation with non-legumes: an achievable target or a dogma? - Curr. Sci. India 92: 317-322.

[67] Sakalli, A. Simpson, D. (2012): Towards the use of dynamic growing seasons in a chemical transport model. - Biogeosciences 9: 5161-5179. doi:10.5194/bg-9-5161-2012.

[68] Sauer, J. D. (1998): Plant Migration the Dynamics of Geographic Patterning in Seed Plant Species. - University of California Press, Berkeley and Los Angeles, California.

[69] Schmithüsen, J. (1968): Allgemeine Vegetationsgeographie, 3. Auflage, 12. - Walter De Gruyter \& Co., Berlin, 7. (in German).

[70] Schmithüsen, J. (1976): Atlas zur Biogeographie (Meyers großer physischer Weltatlas, Bd. 3). - Bibliographisches Institut, Mannheim, Wien, Zürich, 1976.

[71] Schouw, J. F. (1823): Grundzüge einer allgemeinen Pflanzengeographie. - Berlin, De Gruyter.

[72] Schwintzer, C. R., Tjepkema, J. D. (1990): The Biology of Frankia and Actinorhizal Plants. - Academic Press, Inc., San Diego, California, USA.

[73] Sharma, E., Ambasht, R. S. (1991): Biomass, productivity and energetics in Himalayan Alder Plantations. - Annals of Botany, London, 67: 285-293.

[74] Simpson, D., Benedictow, A., Berge, H., Bergstro“m, R., Emberson, L. D., Fagerli, H., Flechard, C. R., Hayman, G. D., Gauss, M., Jonson, J. E., Jenkin, M. E., Nyíri, A., Richter, C., Semeena, V. S., Tsyro, S., Tuovinen, J.-P., Valdebenito, A., Wind, P. (2012): The EMEP MSC-W chemical transport model - technical description. - Atmospheric Chemistry and Physics 12: 7825-7865. doi:10.5194/acp-12-7825-2012.

[75] Siriri, D., Wilson, J., Coe, R., Tenywa, M. M., Bekunda, M. A., Ong, C. K., and Black, R. C. (2013): Trees improve water storage and reduce soil evaporation in agroforestry systems on bench terraces in SW Uganda. - Agroforest Systems 87: 45-58. doi:10.1007/s10457-012-9520-x.

[76] Skjøth, C. A., Geels, C., Hvidberg, M., Hertel, O., Brandt, J., Frohn, L. M., Hansen, K. M., Hedegaard, G. B., Christensen, J. H., and Moseholm, L. (2008): An inventory of tree species in Europe - an essential data input for air pollution modelling. - Ecological 
Modelling 217: 292-304.

[77] Smith, B., Prentice, I. C., Sykes, M. T. (2001): Representation of vegetation dynamics in the modelling of terrestrial ecosystems: comparing two contrasting approaches within European climate space. - Global Ecology and Biogeography 10: 621-637, doi:10.1046/j.1466-822X.2001.t01-1-00256.x.

[78] Sykes, M. T., Prentice, I. C., Cramer, W. (2008): A bioclimatic model for the potential distributions of north European tree species under present and future climates RID B8221-2008. - Journal of Biogeography 23: 203-233.

[79] Thomas, C. D., Cameron, A., Green, R. E., Bakkenes, M., Beaumont, L. J., Collingham, Y. C., Erasmus, B. F. N., Ferreira de Siqueira, M., Grainger, A., Hannah, L., Hughes, L., Huntley, B., van Jaarsveld, A. S., Midgley, G. F., Miles, L., Ortega-Huerta, M. A., Peterson, A. T., Philips, O. L., Williams, S. E. (2003): Extinction risk from climate change. - Nature 427: 145-148. doi:10.1038/nature02121.

[80] Tropicos (2009): Missouri Botanical Garden. - http://www.tropicos.org (last access: 14 May 2009).

[81] Tutin, T. G., Heywood, V. H., Burges, N. A., Valentine, D. (2001): Flora Europaea, Royal Botanical Garden Edinburgh, Vol. 1-5. - Cambridge University Press. http://www.rbg-Ib2.rbge.org.uk/FE/fe.html (last access: 29 June 2009).

[82] U.S. Forest Service (2008): Fire effects information system. http://www.fs.fed.us/database/feis/plants/tree/index.html (last access: 4 December 2010).

[83] USDA-NRCS (2009): PlantS Database. - National Plant Data Center, Baton Rouge, LA 70874-4490, USA. http://plants.usda.gov (last access: 14 May 2009).

[84] Van Miegroet, H., Cole, D. W., Binkley, D., Sollins, P. (1989): The effect of nitrogen accumulation and nitrification on soil chemical properties in alder forests. - In: Olson, R. Lefohn, A., (eds.) Effects of Air Pollution on Istern Forests. Air and Waste Management Association, Pittsburgh, Pa. 515-528.

[85] Van Minnen, J. G., Leemans, R., Ihle, F. (2000): Defining the importance of including transient ecosystem responses to simulate $\mathrm{C}$-cycle dynamics in a global change model. Global Change Biology 6: 595-611.

[86] Vitousek, P. M., Hattenschwiler, S., Olander, L., Allison, S. (2002): Nitrogen and nature. - Ambio 31: 97-101.

[87] Wajja-Musukwe, T. N., Wilson, J., Sprent, J. I. (2008): Tree growth and management in Ugandan agroforestry systems: effects of root pruning on tree growth and crop yield. Tree Physiology 28: 233-242.

[88] Walter, H., Lieth, H. (1967): Climate Diagram World Atlas. - Fischer Verlag, Jena.

[89] Walther, G.-R., Post, E., Convey, P., Menzel, A., Parmesan, C., Beebee, T. J. C., Fromentin, J.-M., Hoegh-Guldberg, O., Bairlein, F. (2002): Ecological responses to recent climate change. - Nature 416: 389-394.

[90] Wang, Y. P., Houlton, B. Z., Field, C. B. (2007): A model of bio-geochemical cycles of carbon, nitrogen, and phosphorus including symbiotic nitrogen fixation and phosphatase production. - Global Bio-geochemical Cycles 21. GB1018. doi:10.1029/2006GB002797.

[91] Wheeler, C. T., Miller, I. M. (1997): Current and potential uses of actinorhizal plants in Europe. - In: Schwintzer, C. R. and Tjepkema, J. D (eds.) The Biology of Frankia and Actinorhizal Plants. Academic Press, San Diego, CA 365-489.

[92] Wiedmer, E., Senn-Irlet, B. (2006): Biomass and primary productivity of an Alnus viridis stand: a case study from the Schachental valley, Switzerland. - Botanica Helvetica 116: $55-64$.

[93] Willmott, C. J. (1982): Some comments on the evaluation of model performance. Bulletin of the American Meteorological Society 63: 1309-1313.

[94] Woodward, F. I. (1996): Climate and Plant Distribution. - Cambridge University Press, UK, Cambridge, Great Britain, 117.

[95] Woodward, F. I. Williams, B. G. (1987): Climate and plant distribution at global and local scales. - Vegetatio 69: 189-197. 
[96] WRCC (2009): Istern Regional Climate Center, Climate of Alaska. http://www.wrcc.dri.edu/narratives/ALASKA.htm, (last access: 10 October 2009).

[97] Wu, T., Wu, M., Yu, M., Xiao, J. (2011): Plant distribution in relation to soil conditions in Hangzhou by coastal Itlands China. - Pakistan Journal of Botany 43: 2331-2335.

[98] WWF (2009): World Wildlife Fund. Online database of species distributions, version January-06. - http://www.worldwildlife.org (last access: 10 October 2009).

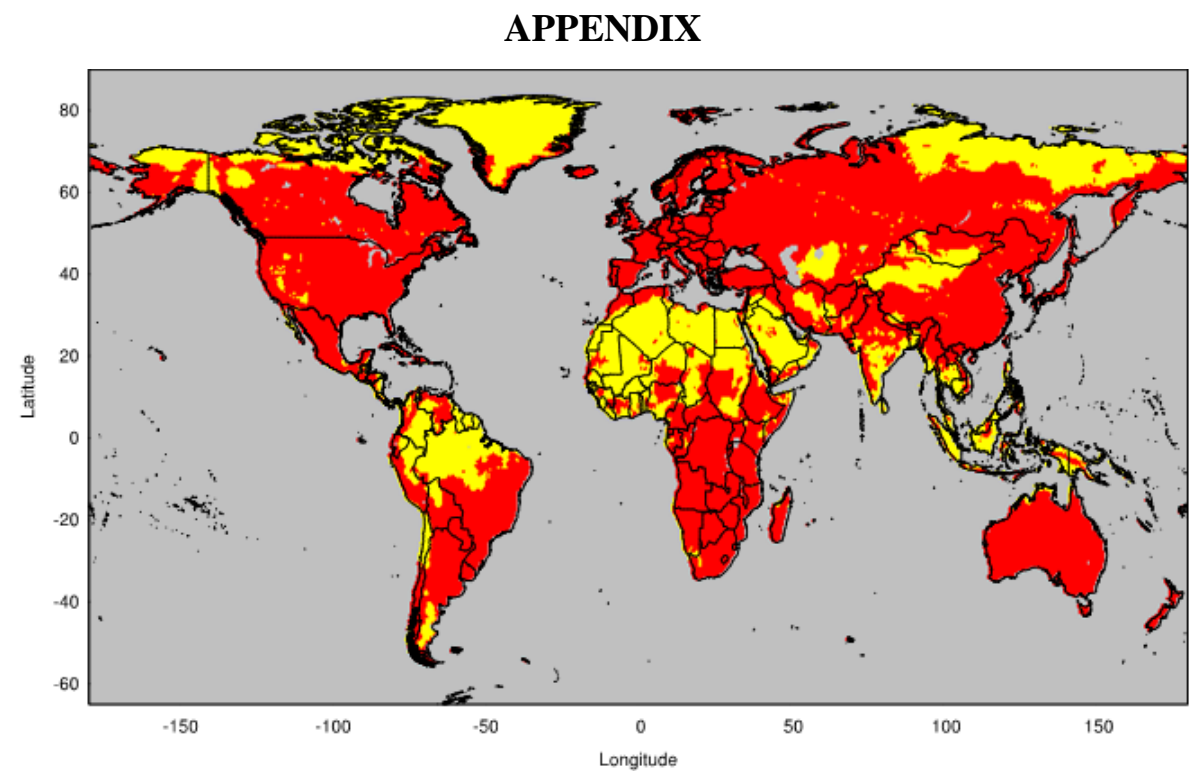

Figure A1. Distribution of grid elements (red) which were identified as potential sites with alder based on the climate functions 1 ...3 (see Fig. 3). Yellow: grid elements were not identified as potential distribution area for alder.

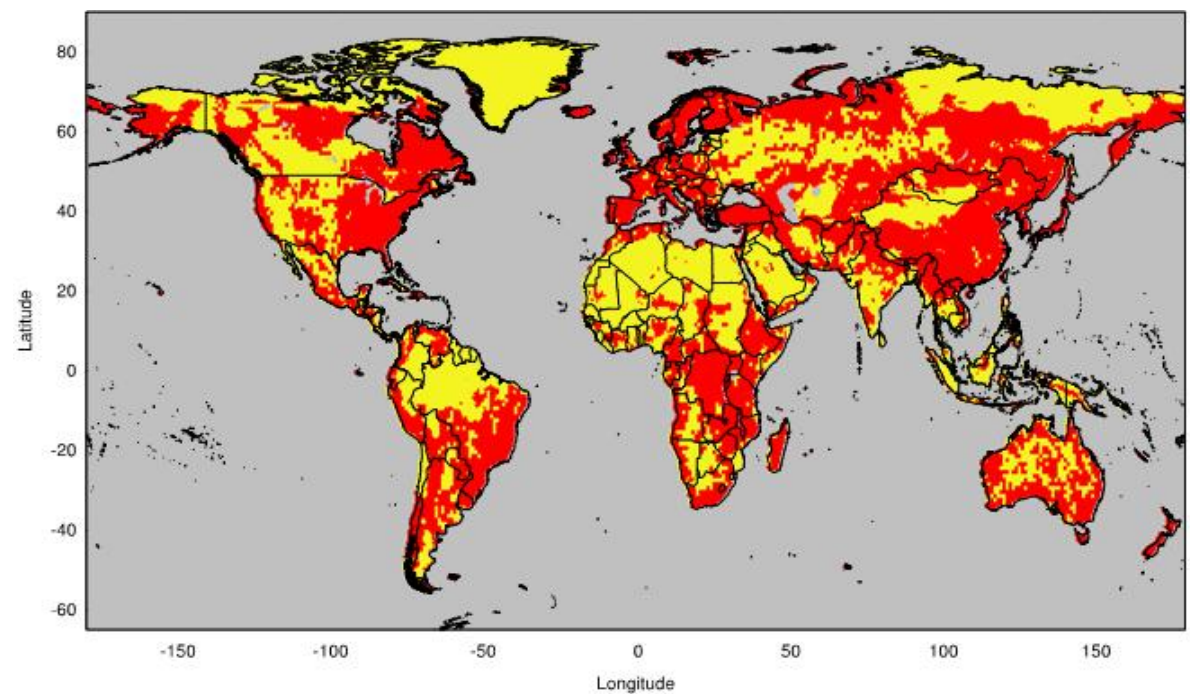

Figure A2. Distribution of grid elements (red) which were identified as potential sites with alder based on the climate functions $1 . . .3$ (see Fig. 3). In this version of the model, restriction by soil units as found in Tab. 1 was applied. Yellow: grid elements were not identified as potential distribution area for alder. 


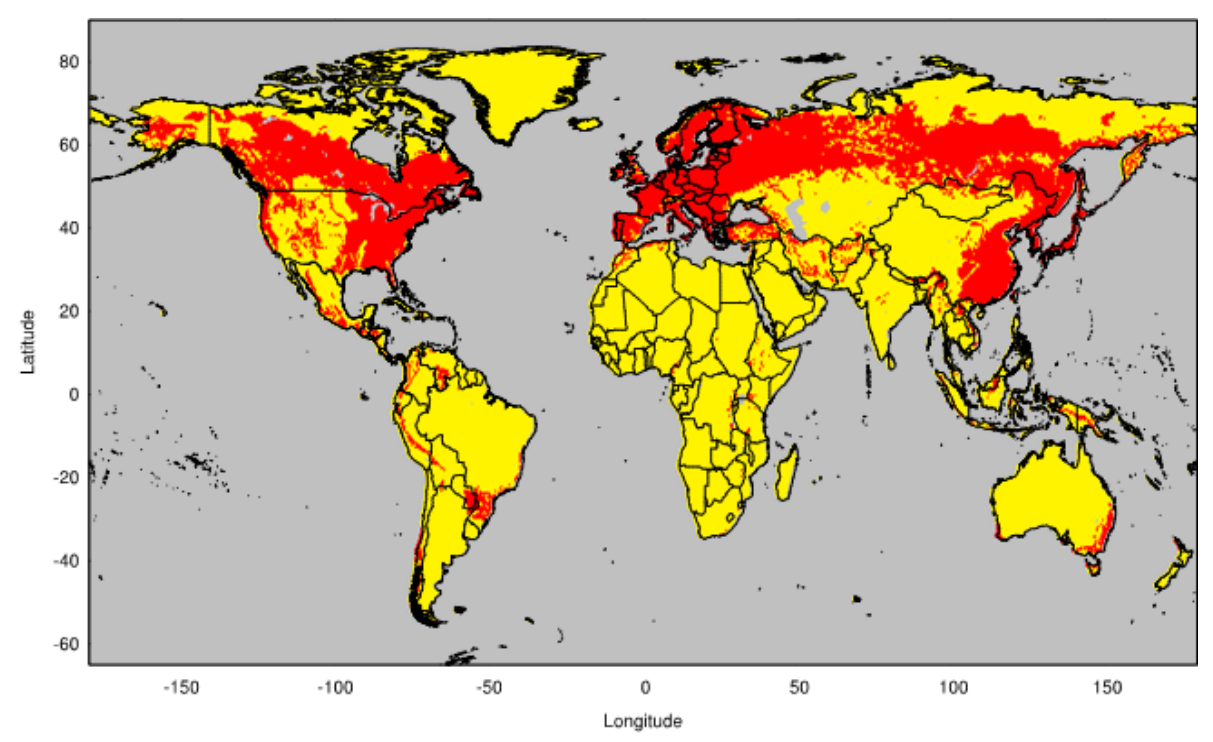

Figure A3. Distribution of grid elements (red) which were identified as potential sites with alder based on the climate functions $1 . . .3$ (see Fig. 3). In this version of the model, restriction by vegetation types (see Tab. 2) was applied. Yellow: grid elements were not identified as potential distribution area for alder. 